U.S. Department of the Interior

U.S. Geological Survey

\title{
HYDROGEOLOGY AND SIMULATION OF GROUND-WATER FLOW AT THE GETTYSBURG ELEVATOR PLANT SUPERFUND SITE, ADAMS COUNTY, PENNSYLVANIA
}

Open-File Report 00-185

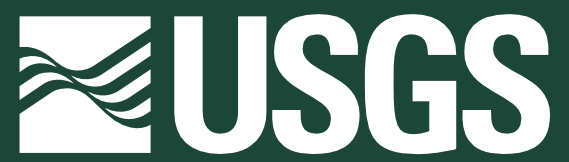


U.S. Department of the Interior

U.S. Geological Survey

\section{HYDROGEOLOGY AND SIMULATION OF GROUND-WATER FLOW AT THE GETTYSBURG ELEVATOR PLANT SUPERFUND SITE, ADAMS COUNTY, PENNSYLVANIA}

by Dennis J. Low, Daniel J. Goode, and Dennis W. Risser

Open-File Report 00-185 


\section{U.S. DEPARTMENT OF THE INTERIOR \\ BRUCE BABBITT, Secretary}

\section{U.S. GEOLOGICAL SURVEY}

Charles G. Groat, Director

For additional information

write to:

District Chief

U.S. Geological Survey

840 Market Street

Lemoyne, Pennsylvania 17043-1586

Email: dc_pa@usgs.gov
Copies of this report may be

purchased from:

U.S. Geological Survey

Branch of Information Services

Box 25286

Denver, Colorado 80225-0286 


\section{CONTENTS}

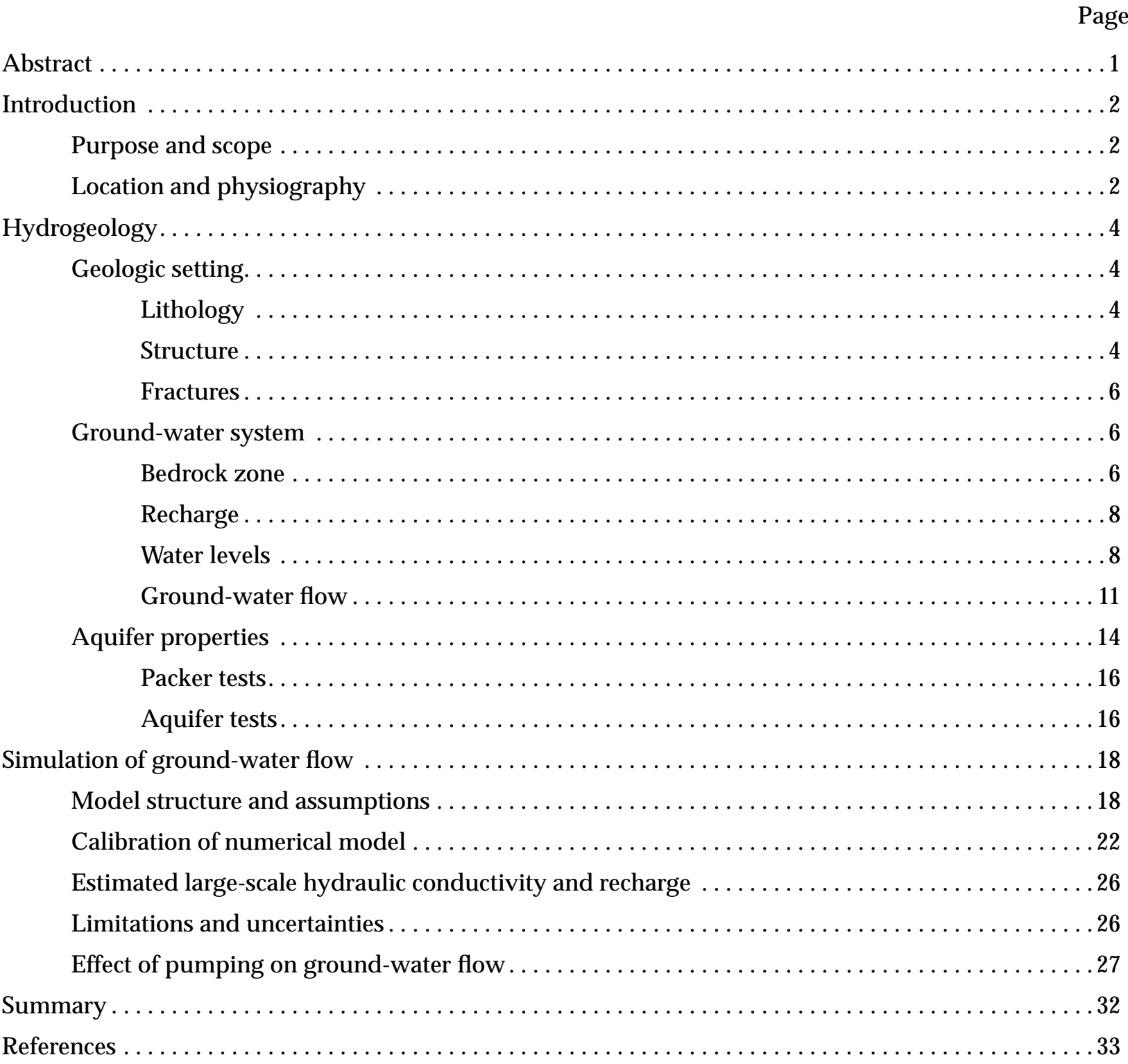




\section{ILLUSTRATIONS}

Page

Figures 1-3. Maps showing location of:

1. Study area showing the Gettysburg Elevator Plant Superfund Site, general geology, well locations, streams, and ground-water-flow model boundary, Gettysburg Elevator Plant Superfund Site, Gettysburg, Pennsylvania .......................

2. Selected monitor wells, geologic sections, natural-gamma logs and natural-gamma-log correlations, and screened intervals . . . . . . . 5

3. Fracture traces, lineaments, and selected wells in the vicinity of the Gettysburg Elevator Plant Superfund Site . . . . . . . . . . . . . 7

4. Hydrograph of observation well AD-146, near York Springs, Adams County,

Pennsylvania $(1990-96) \ldots \ldots \ldots \ldots \ldots \ldots \ldots \ldots \ldots \ldots \ldots \ldots$

5. Graph showing short-term responses to precipitation and changes in discharge rates of the extraction system at selected wells $\ldots \ldots \ldots \ldots \ldots \ldots \ldots \ldots \ldots \ldots \ldots \ldots$

6-7. Maps showing:

6. Potentiometric surface and isoconcentration lines showing total volatile organic concentration in the bedrock zone, October $1,1996 \ldots \ldots \ldots \ldots \ldots$

7. Model grid, boundaries, stream cells, and locations of extraction wells . . . . . 19

8. Schematic cross-section of model structure showing thickness of 16 layers and vertical discretization of dipping beds with high (zones 6, 7, 8, and 9) and low hydraulic conductivities (zones $1,2,3,4$, and 5 ) . . . . . . . . . . 20

9-12. Maps showing:

9. Simulated potentiometric surface under no-pumping steady-state conditions in model layer 7 representing unweathered, fractured bedrock between

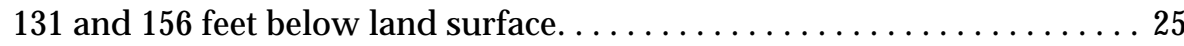

10. Simulated contributing areas to extraction wells under long-term steady-state conditions............................. 28

11. Simulated contributing areas to onsite extraction wells under long-term

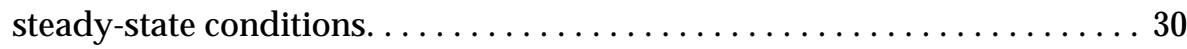

12. Simulated contributing areas to offsite extraction wells under long-term

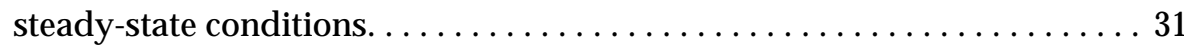




\section{TABLES}

Table 1. Record of selected wells in the vicinity of the Gettysburg Elevator Plant Superfund Site, Gettysburg, Pennsylvania . . . . . . . . . . . . . . . . . . . 9

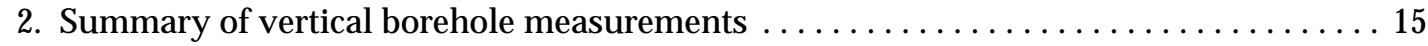

3. Estimates of hydraulic conductivity from packer tests by Rizzo Associates, 1991, in seven monitor wells . . . . . . . . . . . . . . . . . . . . . . . . 16

4. Reported maximum drawdowns at selected monitor wells during the 24-hour constant rate discharge tests of wells AD-654 and AD-655 . . . . . . . . . . 17

5. Estimates of transmissivity and storage coefficient during the 1996 implementation of the existing ground-water extraction system $\ldots \ldots \ldots \ldots \ldots \ldots \ldots \ldots \ldots \ldots$

6. Water-level measurements used for calibration of the ground-water-flow model . . . . 23

7. Optimum values for storage coefficient and hydraulic conductivity and normalized sensitivity of hydraulic conductivity parameters for calibrated simulation

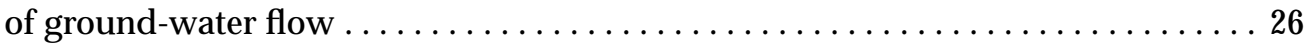

8. Steady-state water budgets for the ground-water system simulated in the model . . . . 27

9. Estimates of ground-water recharge from the Gettysburg Elevator Plant Superfund Site that is captured by extraction wells $\ldots \ldots \ldots \ldots \ldots \ldots \ldots 29$ 


\section{CONVERSION FACTORS AND ABBREVIATIONS}

Multiply

inch (in)

foot (ft)

mile (mi)

acre

square mile $\left(\mathrm{mi}^{2}\right)$

gallon per minute (gal/min)

inch per year (in/yr)

foot per day $(\mathrm{ft} / \mathrm{d})$

gallon per minute per foot $[(\mathrm{gal} / \mathrm{min}) / \mathrm{ft}]$

foot squared per day $\left(\mathrm{ft}^{2} / \mathrm{d}\right)$

degree Fahrenheit $\left({ }^{\circ} \mathrm{F}\right)$

By

$\underline{\text { To obtain }}$

Length

$$
2.54
$$

0.3048

1.609

Area

4,047

2.590

Flow rate

0.06309

25.4

Hydraulic conductivity

0.3048

Specific capacity

0.2070

Transmissivity

0.09290

Temperature

${ }^{\circ} \mathrm{C}=5 / 9\left({ }^{\circ} \mathrm{F}-32\right)$ centimeter

meter

kilometer

square meter

square kilometer

liter per second

millimeter per year

meter per day

liter per second per meter

meter squared per day

degree Celsius

Sea level: In this report, "sea level" refers to the National Geodetic Vertical Datum of 1929-a geodetic datum derived from a general adjustment of the first-order level nets of the United States and Canada, formerly called Sea Level Datum of 1929. 


\title{
HYDROGEOLOGY AND SIMULATION OF GROUND- WATER FLOW AT THE GETTYSBURG ELEVATOR PLANT SUPERFUND SITE, ADAMS COUNTY, PENNSYLVANIA
}

\author{
by Dennis J. Low, Daniel J. Goode, and Dennis W. Risser
}

\begin{abstract}
Ground water in Triassic-age sedimentary fractured-rock aquifers in the area of Gettysburg, Pa., is used as drinking water and for industrial and commercial supply. In 1983, ground water at the Gettysburg Elevator Plant was found by the Pennsylvania Department of Environmental Resources to be contaminated with trichloroethene, 1,1,1-trichloroethane, and other synthetic organic compounds. As part of the U.S. Environmental Protection Agency's Comprehensive Environmental Response, Compensation, and Liability Act, 1980 process, a Remedial Investigation was completed in July 1991, a method of site remediation was issued in the Record of Decision dated June 1992, and a Final Design Report was completed in May 1997. In cooperation with the U.S. Environmental Protection Agency in the hydrogeologic assessment of the site remediation, the U.S. Geological Survey began a study in 1997 to determine the effects of the onsite and offsite extraction wells on ground-water flow and contaminant migration from the Gettysburg Elevator Plant. This determination is based on hydrologic and geophysical data collected from 1991 to 1998 and on results of numerical model simulations of the local ground-water flow-system.
\end{abstract}

The Gettysburg Elevator Site is underlain by red, green, gray, and black shales of the Heidlersburg Member of the Gettysburg Formation. Correlation of natural-gamma logs indicates the sedimentary rock strike about N. $23^{\circ}$ E. and dip about $23^{\circ}$ NW. Depth to bedrock onsite commonly is about 6 feet but offsite may be as deep as 40 feet.

The ground-water system consists of two zones-a thin, shallow zone composed of soil, clay, and highly weathered bedrock and a thicker, nonweathered or fractured bedrock zone. The shallow zone overlies the bedrock zone and truncates the dipping beds parallel to land surface. Diabase dikes are barriers to ground-water flow in the bedrock zone. The ground-water system is generally confined or semi-confined, even at shallow depths.

Depth to water can range from flowing at land surface to more than 71 feet below land surface. Potentiometric maps based on measured water levels at the Gettysburg Elevator Plant indicate ground water flows from west to east, towards Rock Creek. Multiple-well aquifer tests indicate the system is heterogeneous and flow is primarily in dipping beds that contain discrete secondary openings separated by less permeable beds. Water levels in wells open to the pumped bed, as projected along the dipping stratigraphy, are drawn down more than water levels in wells not open to the pumped bed.

Ground-water flow was simulated for steady-state conditions prior to pumping and long-term average pumping conditions. The three-dimensional numerical flow model (MODFLOW) was calibrated by use of a parameter estimation program (MODFLOWP). Steady-state conditions were assumed for the calibration period of 1996. An effective areal recharge rate of 7 inches was used in model calibration. The calibrated flow model was used to evaluate the effectiveness of the current onsite and offsite extraction well system. The simulation results generally indicate that the extraction system effectively captures much 
of the ground-water recharge at the Gettysburg Elevator Plant and, hence, contaminated ground-water migrating from the site. Some of the extraction wells pump at low rates and have very small contributing areas. Results indicate some areal recharge onsite will move to offsite extraction wells.

\section{INTRODUCTION}

The Gettysburg Elevator Plant Superfund Site (Elevator Site) covers approximately 90 acres along the west side of Biglerville Road (State Route 34), about $1.5 \mathrm{mi}$ north of Gettysburg, Pa. (fig. 1). The land was used as farm or pasture prior to 1968. The Elevator Plant was constructed during 1968 and early 1969 for manufacturing elevator and escalator components. Chemicals used in the processing of elevator and escalator components include solvents, paints, cutting and lubricating oils, and insulation boards. Waste chemicals, principally trichloroethene (TCE) and 1,1,1-trichloroethane (TCA), from processing activities generally were placed in drums, pumped into large holding tanks for offsite disposal, or discharged into the municipal sewer system. Ground-water samples from monitor wells at the facility have contained TCE, TCA, and other dense nonaqueous phase liquids (DNAPL's).

The Elevator Site was originally investigated on the basis of complaints from local residents by the Pennsylvania Department of Environmental Resources (PaDER) in 1983 (Pennsylvania Environmental Hearing Board, 1988-1989). In October 1983, PaDER confirmed the presence of volatile organic compounds (VOC's) in surface water, ground water, and soil from the Elevator Site. As part of the Comprehensive Environmental Response, Compensation, and Liability Act (CERCLA) process, a Remedial Investigation (RI) was completed in July 1991 (Rizzo Associates, 1991), a method of site remediation was issued in the Record of Decision (ROD) dated June 1992 (U.S. Environmental Protection Agency, 1992), and a Final Design Report was completed in May 1997 (Cummings/Riter, 1997).

In September 1993, the U.S. Geological Survey (USGS), in cooperation with the U.S. Environmental Protection Agency (USEPA), began a series of hydrologic investigations to evaluate the Remedial Design (RD) at the Elevator Site. In March 1999, the USGS began preparing a ground-water-flow model of the Elevator Site and adjacent areas to help evaluate the effectiveness of the remediation method.

\section{Purpose and Scope}

This report evaluates whether ground-water pumping at recovery wells is likely to contain the migration of VOC's from the Elevator Site. This report (1) summarizes available hydrogeologic and ground-water data from the Elevator Site and adjacent areas; (2) describes the numerical simulation used to model the study area; and (3) evaluates the effectiveness of the extraction system in capturing VOC's at the Elevator Site. Much of the data used to evaluate the ground-water extraction system was obtained from the RI, RD, and Final Design studies (Rizzo Associates, 1991; Cummings/Riter, 1997; 1998).

\section{Location and Physiography}

The Elevator Site lies within the Gettysburg-Newark Lowland Section of the Piedmont Physiographic Province (Fenneman, 1938; Berg and others, 1989) and is in the Rock Creek watershed. Rock Creek flows south and is located about $0.75 \mathrm{mi}$ to the east. Regionally, the topography is characterized by rolling hills and broad valleys. Altitudes in the vicinity of the Elevator Site range from $480 \mathrm{ft}$ (near Rock Creek) to $660 \mathrm{ft}$ (diabase ridge northwest of Elevator Site) above sea level. 


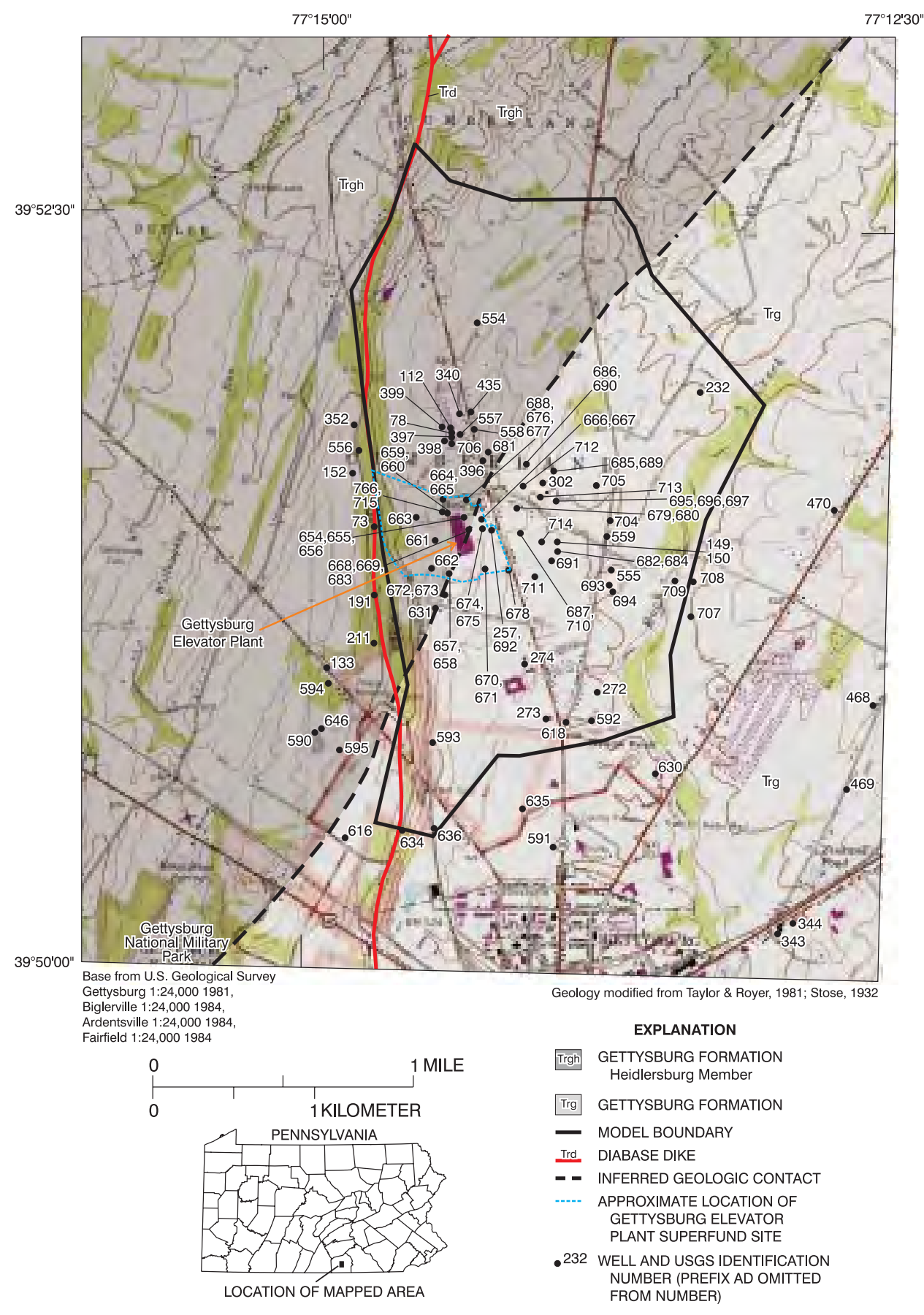

Figure 1. Location of study area showing the Gettysburg Elevator Plant Superfund Site, general geology, well locations, streams, and ground-water-flow model boundary, Gettysburg, Pennsylvania (well information is presented in table 1). 


\section{HYDROGEOLOGY}

At the Elevator Site, the fractured bedrock generally acts as a confined aquifer that is recharged by precipitation and discharges water to springs and streams. Ground-water flow systems tend to be of local rather than regional extent. Lithology, geologic structure, and the ground-water system are described below to provide a framework for understanding the numerical model simulation.

\section{Geologic Setting}

The Elevator Site is underlain by moderately dipping Triassic-age sedimentary rocks of the Gettysburg Formation and bordered to the west (fig. 1) by Triassic to Jurassic-age intrusive dikes of diabase (Stose, 1932; Wood, 1980; Taylor and Royer, 1981). The Gettysburg Formation is moderately resistant to weathering, generally forming broad valleys. The diabase is highly resistant to weathering, forming hills and ridges that commonly represent surface-water divides.

\section{Lithology}

The Gettysburg Formation in general is soft, reddish-brown shale and red-brown, fine- to mediumgrained sandstone with minor amounts of yellowish-brown shale and sandstone. The Gettysburg Formation contains a prominent middle member, named the Heidlersburg. At the Elevator Site, the Heidlersburg Member consists predominantly of red shale, with some green, gray, and black shale; interbeds of gray to white sandstone are rare. Recent work in the Gettysburg National Military Park, located just west of Gettysburg (fig. 1), identified numerous carbonate units associated with the Heidlersburg Member sandstones (Tom Armstrong, U.S. Geological Survey, oral commun., 1999). The contact between the Heidlersburg Member and the Gettysburg Formation is gradational over approximately 200 to $300 \mathrm{ft}$ (Root, 1989). Most of the Elevator Site is underlain by the Heidlersburg Member (fig. 1).

A $100-\mathrm{ft}$ wide diabase dike that trends roughly north-south is located about 1,200 $\mathrm{ft}$ west of the Elevator Site (fig. 1). The fine-grained, dark gray to black diabase dike consists of plagioclase and is typically low in olivine and titanium. The diabase, which has a composition similar to a basalt, is quartz normative (high silica content, greater than 50 percent), indicating it was intruded in the late stages of rifting.

The diabase is surrounded by a thin metamorphic zone of altered rock or hornfels. Hornfels are finegrained rock composed of a mosaic of equidimensional grains without preferred orientation. Most hornfels are a product of heating associated with the diabase. Within the hornfels are porphyroblasts of Andalusite and Cordierite (approximately $0.1 \mathrm{in}$. in diameter) formed in a temperature range of about 500 to $600^{\circ} \mathrm{C}$ and a pressure of a few kilobars (equivalent to burial of less than $6 \mathrm{mi}$ ).

\section{Structure}

The Gettysburg Basin appears to be a half-graben structure. The northwestern border is formed by faults with a predominantly normal movement, and the southeastern border is formed as a flexure. This causes the majority of the sediments within the basin to exhibit a predominantly northwest dip along strikes approximately parallel to the axis of the basin (Wood, 1980; Taylor and Royer, 1981).

Rizzo Associates (1991) have determined, on the basis of natural-gamma logs, that the beds at the Elevator Site have an average strike of about N. $23^{\circ}$ E. and dip about $23^{\circ} \mathrm{NW}$. Examples of correlations of natural-gamma logs from selected wells in the study area are presented in figure 2 . Thin gray or black shale beds with high natural-gamma activity are most commonly found in the Heidlersburg Member. These marker beds can be correlated over distances of 2,400 ft or greater. 


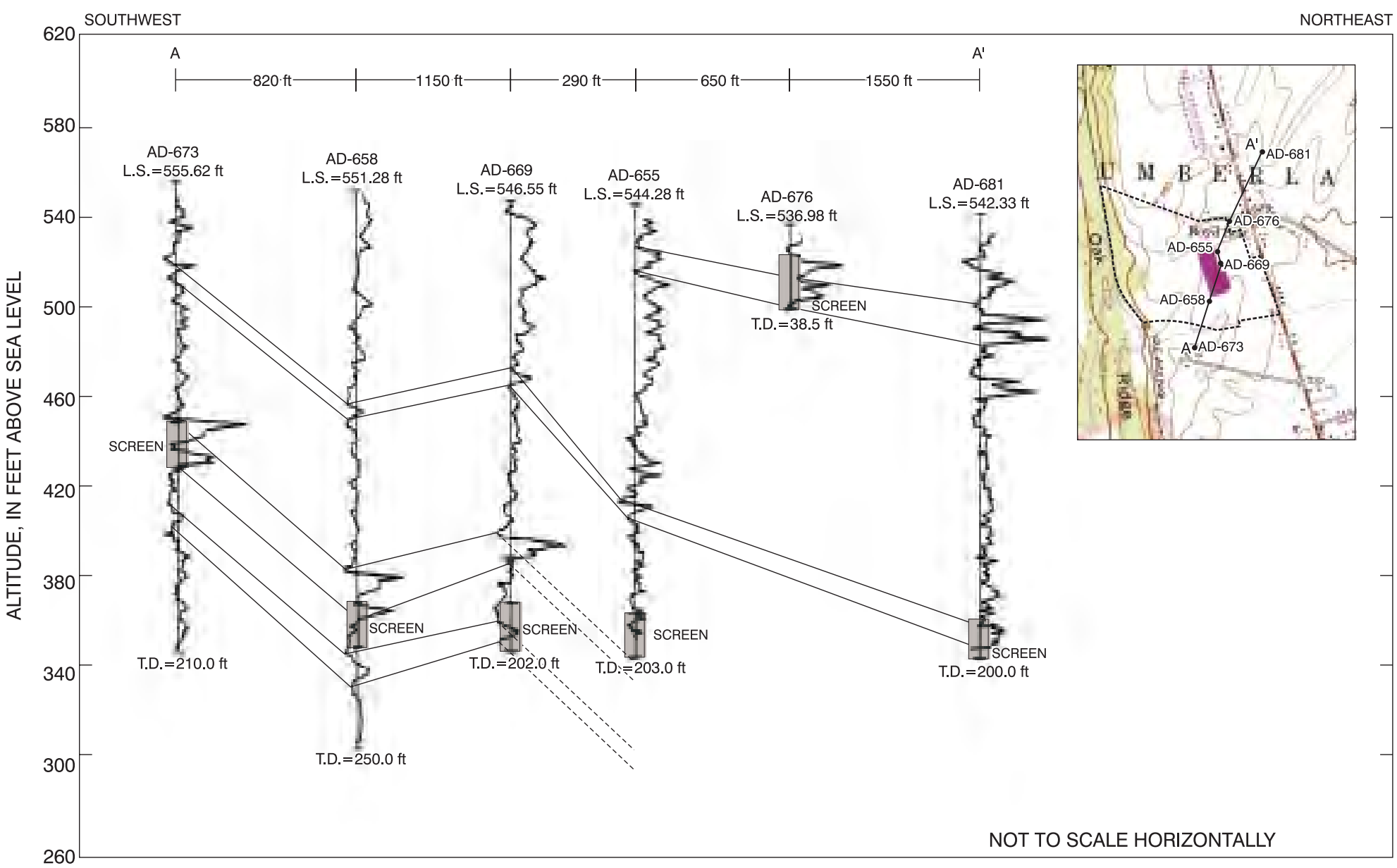

Figure 2. Location of selected monitor wells, geologic sections, natural-gamma logs and natural-gamma-log correlations, and screened intervals, Gettysburg Elevator Plant Superfund Site, Gettysburg, Pennsylvania (modified from Rizzo Associates, 1991, fig. 3-10). [L.S. - landsurface altitude; T.D. - total depth drilled; ft, feet]. 


\section{Fractures}

Wood (1980) and Rizzo Associates (1991) identified a number of fracture traces or lineaments at and in proximity to the Elevator Site (fig. 3). One of the largest fracture traces mapped, trending N. $20^{\circ}$ W., is nearly parallel to Biglerville Road immediately behind the Elevator Plant. Another, less prominent fracture trace trending N. $43^{\circ}$ E. passes along the northwest corner of the Elevator Plant. This fracture may have an appreciable affect on ground-water flow. According to Rizzo Associates (1991, p. 3-10), "Water levels measured in nested monitoring wells PMW-7A and PMW-7B installed along this fracture trace, indicate an upward vertical gradient is present. This upward gradient was not observed in other nested well locations."

On the basis of a number of site borings, Rizzo Associates (1991) determined that joints are nearly vertical with two predominant orientations of N. $65^{\circ}$ E. and N. $155^{\circ}$; a minor joint set trends about N. $5^{\circ}$ to $10^{\circ} \mathrm{E}$. Evaluations of bedrock cores and packer tests in wells at the Elevator Site indicated most permeable zones were located within $40 \mathrm{ft}$ of the land surface. Bedding-plane partings were the most common fractures encountered, although near-vertical joints also were observed. In general, the distance between joints increased with depth (Rizzo Associates, 1991).

Sandstone beds in and near the Gettysburg Military Park, located west of Gettysburg (fig. 1), have more fractures than the shale beds, and the fractures are more systematic (Tom Armstrong, U.S. Geological Survey, oral commun., 1999). Although the intervening shales beds are highly fractured, the fractures are very small, inches to a few feet in length, with convoluted pathways. Breaks in the sandstones typically do not cross into and through the shale beds.

\section{Ground-Water System}

Ground water in the rocks underlying the Elevator Site and surrounding area originates from infiltration of local precipitation. After infiltrating through soil and regolith, the water moves through near-vertical and horizontal fractures and joints in the shale and sandstone bedrock. Ground water is generally unconfined at shallow depths but becomes confined as it moves in a downdip direction.

The ground-water system at the Elevator Site can be described as consisting of a dipping bedrock zone overlain by a thin, approximately 6-ft thick, shallow zone that is composed of soil, clay, and highlyweathered bedrock. The shallow zone truncates the dipping bedrock zone parallel to land surface. Diabase dikes are considered a barrier to lateral flow in the bedrock zone.

\section{Bedrock Zone}

The bedrock zone consists of competent, but fractured shale and siltstone that contain minor intervening sandstone. The water-producing or water-receiving intervals consist almost entirely of secondary openings such as bedding planes, fractures, faults, and joints. Joints parallel to bedding probably serve as the primary flowpaths in the bedrock zone. High-angle joints can provide the interconnection between water-producing or water-receiving intervals (Lewis-Brown and Jacobsen, 1995). At the Elevator Site, the water-producing or water-receiving intervals can be visualized as dipping $\left(23^{\circ} \mathrm{NW}\right.$.), over-lapping, lens-shaped, and discontinuous aquifers. These aquifers are commonly separated by tens to hundreds of feet of shale with negligible effective porosity or permeability (Wood, 1980; Taylor and Royer, 1981, pl. 1). 


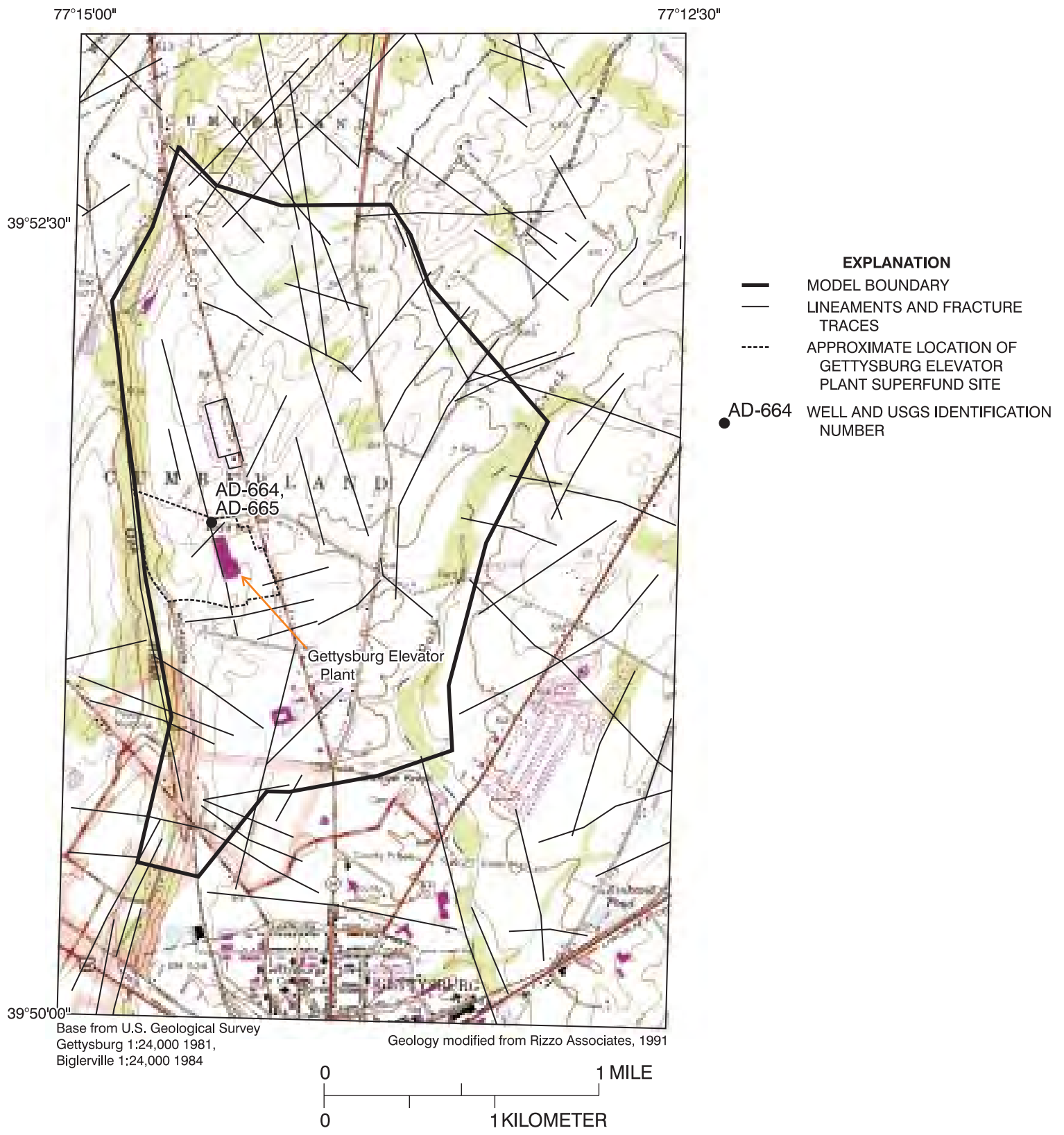

Figure 3. Location of fracture traces, lineaments, and selected wells in the vicinity of the Gettysburg Elevator Plant Superfund Site, Gettysburg, Pennsylvania (modified from Rizzo Associates, 1991). 


\section{Recharge}

The average annual precipitation from 1872 to 1993 at the Eisenhower National Historic Site, located about 2 mi west of Gettysburg, Pa., is 43.44 in. (National Oceanic and Atmospheric Administration, 1993); however, only a small part of this precipitation recharges ground water. Taylor and Royer (1981, p. 4) estimated that the effective areal recharge to the ground-water system averages only $7 \mathrm{in} / \mathrm{yr}$ for Adams County. In their regional ground-water-flow model of the Lower Susquehanna River Basin, Gerhart and Lazorchick (1988, table 12) estimated average annual ground-water recharge as ranging from 2.6 to $9.1 \mathrm{in}$. for the Gettysburg area. These estimates were derived by varying recharge on the basis of lithology and precipitation during model calibration. Effective areal recharge may not be areally uniform because it is affected by lithology, soil type, soil moisture, temperature, slope, and other factors including impervious surface area. For example, Schreffler (1996) reported the clay-rich soil and thin weathered bedrock zone of the Coffman Hill diabase sill in Bucks County, Pa., permitted very little areal recharge.

\section{Water Levels}

Water levels measured in wells where the ground water is unconfined indicate the level of the water table. Where ground water is confined, water levels measured in wells indicate the level of a potentiometric surface. Most wells listed in table 1 that are not classified as monitor or extraction wells are completed as open boreholes. Water levels measured in deep, open-borehole wells represent a composite of the water levels in multiple aquifers penetrated by each well.

Ground-water levels fluctuate in response to recharge from precipitation, discharge from pumping wells, evapotranspiration, inflow from or outflow to streams, and many other factors. In the Gettysburg area, where precipitation is distributed nearly evenly year-round, water levels generally rise during the late fall, winter, and early spring when soil-moisture deficits and evapotranspiration are at a minimum and recharge is at a maximum. Water levels generally decline during the late spring, summer, and early fall when soil-moisture deficits and evapotranspiration are at a maximum and recharge is at a minimum. The magnitude of seasonal fluctuations or shorter-term changes in water levels in response to recharge is related to aquifer properties. After recharge, the water-level rise may be greater and may be sustained longer in aquifers with low permeability than in aquifers with high permeability.

A hydrograph (1990-96) for observation well AD-146, near York Springs in Adams County is shown on figure 4. In southcentral Pennsylvania, below-normal water levels began in October 1990 and continued through May 1992. Above-normal water levels were recorded throughout 1996. Annual precipitation as measured at the Eisenhower National Historic Site, located about 2 mi west of Gettysburg, was 36.76 in. in 1991, 44.06 in. in 1992, 49.46 in. in 1993, 44.92 in. in 1994, 40.13 in. in 1995, and 65.17 in. in 1996.

Water levels were measured on a monthly basis from March 1994 through January 1995 in 29 wells (Cummings/Riter, 1998). Five additional wells were added to this monitor system in August 1994, and five more monitor wells were added in October 1994. The wells were screened in one water-bearing interval. Screened depths ranged from 25 to $40 \mathrm{ft}$ below land surface (bls) to 278 to $298 \mathrm{ft}$ bls (table 1). Water levels in 16 of the 40 wells measured were affected by pumping well AD-655. During this 11-month period, well AD-655 was actively pumped to contain and extract VOC's at the Elevator Site. 
Table 1. Record of selected wells in the vicinity of the Gettysburg Elevator Plant Superfund Site, Gettysburg, Pennsylvania

[Location of wells are shown in figure 1. gal/min, gallons per minute; (gal $/ \mathrm{min}) / \mathrm{ft}$, gallons per minute per foot of drawdown; mm-dd-yy, month, day, year; --, not available; <, less than; >, greater than; C, commercial; M, monitor; $\mathrm{N}$, industrial; D, domestic; E, extraction; P, public; U, unused public]

\begin{tabular}{|c|c|c|c|c|c|c|c|c|c|c|}
\hline $\begin{array}{l}\text { U.S. } \\
\text { Geological } \\
\text { Survey } \\
\text { well } \\
\text { number }\end{array}$ & $\begin{array}{l}\text { Gettysburg } \\
\text { Elevator Plant } \\
\text { identification } \\
\text { number }\end{array}$ & $\begin{array}{l}\text { Well depth } \\
\text { (feet below } \\
\text { land } \\
\text { surface) }\end{array}$ & $\begin{array}{l}\text { Depth to top and } \\
\text { bottom of open or } \\
\text { screened interval }\end{array}$ & $\begin{array}{l}\text { Reported } \\
\text { yield } \\
\text { (gal } / \mathrm{min} \text { ) }\end{array}$ & $\begin{array}{c}\text { Specific } \\
\text { capacity } \\
\text { (gal/min)/ft }\end{array}$ & $\begin{array}{l}\text { Reported } \\
\text { depth to } \\
\text { water } \\
\text { (feet below } \\
\text { land surface) }\end{array}$ & $\begin{array}{l}\text { Date water } \\
\text { level } \\
\text { measured } \\
\text { (mm-dd-yy) }\end{array}$ & $\begin{array}{l}\text { Reported depth } \\
\text { to water- } \\
\text { bearing zones } \\
\text { (feet below } \\
\text { land surface) }\end{array}$ & $\begin{array}{l}\text { Depth to } \\
\text { bedrock } \\
\text { (feet } \\
\text { below } \\
\text { land } \\
\text { surface) }\end{array}$ & $\begin{array}{l}\text { Water } \\
\text { use }\end{array}$ \\
\hline AD-149 & -- & 200 & $47-$ & 12 & -- & 32 & $03-00-93$ & 180 & -- & $\mathrm{D}$ \\
\hline AD-150 & -- & 240 & $40-$ & 30 & -- & 24 & $03-00-93$ & $95,130,240$ & 40 & $\mathrm{D}$ \\
\hline AD-302 & -- & 240 & -- & 60 & -- & -- & -- & -- & -- & $\mathrm{N}$ \\
\hline AD-303 & -- & 280 & -- & 60 & -- & 13.8 & $07-14-76$ & -- & -- & $\mathrm{N}$ \\
\hline AD-343 & -- & 420 & $57.5-420$ & 295 & 1.1 & 12.9 & $08-10-73$ & $\begin{array}{l}100,200,260 \\
320\end{array}$ & 20 & $\mathrm{P}$ \\
\hline AD-344 & -- & 220 & 220 & 48 & .27 & 10 & $01-30-75$ & $100,150,190$ & 10 & $\mathrm{C}$ \\
\hline AD-555 & -- & 165 & 165 & 3.5 & -- & 46 & 04-00-78 & 85 & 36 & $\mathrm{D}$ \\
\hline AD-559 & -- & 50 & -- & -- & -- & -- & -- & -- & -- & $\mathrm{D}$ \\
\hline AD-591 & -- & 900 & $84-$ & 210 & 2.6 & 15 & $01-14-86$ & $\begin{array}{l}74,157,221, \\
237,368,383, \\
399,421,494, \\
513,621,632, \\
694,732,782, \\
836,879,900\end{array}$ & 4 & U \\
\hline AD-654 & PMW-1A & 45 & $25-$ & 1 & -- & 26.82 & 03-08-99 & -- & 3 & $M$ \\
\hline AD-655 & PMW-1B & 203 & $83-203$ & 14 & .08 & 23.78 & 03-08-99 & 89,190 & 13 & $M$ \\
\hline AD-656 & EW-2 & 115 & $85-$ & 1.5 & -- & 17.37 & 03-08-99 & 96 & 3 & $E$ \\
\hline AD-657 & PMW-2A & 52 & $42-$ & .5 & -- & 27.18 & 03-08-99 & 46 & 5 & $M$ \\
\hline AD-658 & PMW-2B & 205 & $185-205$ & $<.5$ & $<.01$ & 1.89 & 03-08-99 & -- & 14 & M \\
\hline AD-659 & PMW-3A & 55 & $38-$ & $<.5$ & -- & 7.76 & 03-08-99 & 39 & 4 & $M$ \\
\hline AD-660 & PMW-3B & 165 & $145-\quad 165$ & 4 & .04 & 28.43 & 03-08-99 & 64,142 & 11 & $M$ \\
\hline AD-661 & PMW-4 & 232 & $190-$ & 0 & -- & 37.84 & 03-08-99 & -- & 13 & $M$ \\
\hline AD-662 & PMW-5 & 202 & $190-\quad 200$ & 4.5 & .03 & 67.72 & 03-08-99 & 192 & 5 & M \\
\hline AD-663 & PMW-6 & 149 & $123.5-148.5$ & $<.5$ & $<.01$ & 10.84 & 03-08-99 & 167 & 12 & $M$ \\
\hline AD-664 & PMW-7A & 54 & $42-$ & 1.5 & .02 & 1.64 & 03-08-99 & 67 & 13 & M \\
\hline AD-665 & PMW-7B & 210 & $184-$ & .5 & -- & .04 & 03-08-99 & 165,202 & 5 & M \\
\hline AD-666 & PMW-8A & 40 & $30-$ & 3 & .18 & 17.98 & 03-08-99 & 32 & 16 & $M$ \\
\hline AD-667 & PMW-8B & 143 & $127-$ & 9 & -- & 20.19 & 03-08-99 & $49,114,141$ & 3 & $M$ \\
\hline AD-668 & PMW-9A & 50 & $33-$ & $<.5$ & -- & $>36.89$ & 03-08-99 & -- & 13 & $M$ \\
\hline AD-669 & PMW-9B & 183 & $160-$ & 1.5 & .02 & 23.21 & 03-08-99 & 168,193 & 16.5 & $M$ \\
\hline AD-670 & PMW-10A & 42 & $25-$ & 3 & .04 & 10.94 & 03-08-99 & 93 & 16 & $M$ \\
\hline AD-671 & PMW-10B & 234 & $222-$ & $<.5$ & -- & 14.62 & 03-08-99 & -- & 5 & $M$ \\
\hline AD-672 & PMW-11A & 55 & $35-$ & $<.5$ & -- & 28.41 & 03-08-99 & -- & 5 & $M$ \\
\hline AD-673 & PMW-11B & 134 & $109-$ & 1 & -- & 30.32 & 03-08-99 & $\begin{array}{l}18,32,151, \\
153\end{array}$ & 4 & $M$ \\
\hline AD-674 & PMW-12A & 41 & $26-$ & 0 & -- & 5.92 & 03-08-99 & -- & 4 & $M$ \\
\hline AD-675 & PMW-12B & 172 & $152-\quad 172$ & 3 & -- & 12.68 & 03-08-99 & $6,28,44$ & 6 & $M$ \\
\hline AD-676 & PMW-13A & 38 & $23-$ & 6 & -- & 15.60 & 03-08-99 & 34 & 4 & $M$ \\
\hline AD-677 & PMW-13B & 180 & $160-180$ & 40 & -- & 25.92 & 03-08-99 & $121,135,177$ & 4 & M \\
\hline AD-678 & PMW-15 & 169 & $144-$ & 8 & 2.3 & 9.44 & 03-08-99 & $\begin{array}{l}34,41,71,96, \\
99\end{array}$ & 7 & $M$ \\
\hline
\end{tabular}


Table 1. Record of selected wells in the vicinity of the Gettysburg Elevator Plant Superfund Site, Gettysburg, Pennsylvania-Continued

[Location of wells are shown in figure 1. gal/min, gallons per minute; $(\mathrm{gal} / \mathrm{min}) / \mathrm{ft}$, gallons per minute per foot of drawdown; mm-dd-yy, month, day, year; --, not available; <, less than; >, greater than; C, commercial; M, monitor; $\mathrm{N}$, industrial; D, domestic; E, extraction; P, public; U, unused public]

\begin{tabular}{|c|c|c|c|c|c|c|c|c|c|c|}
\hline $\begin{array}{l}\text { U.S. } \\
\text { Geological } \\
\text { Survey } \\
\text { well } \\
\text { number }\end{array}$ & $\begin{array}{c}\text { Gettysburg } \\
\text { Elevator Plant } \\
\text { identification } \\
\text { number }\end{array}$ & $\begin{array}{l}\text { Well depth } \\
\text { (feet below } \\
\text { land } \\
\text { surface) }\end{array}$ & $\begin{array}{l}\text { Depth to top and } \\
\text { bottom of open or } \\
\text { screened interval }\end{array}$ & $\begin{array}{l}\text { Reported } \\
\text { yield } \\
\text { (gal/min) }\end{array}$ & $\begin{array}{c}\text { Specific } \\
\text { capacity } \\
(\mathrm{gal} / \mathrm{min}) / \mathrm{ft}\end{array}$ & $\begin{array}{l}\text { Reported } \\
\text { depth to } \\
\text { water } \\
\text { (feet below } \\
\text { land surface) }\end{array}$ & $\begin{array}{l}\text { Date water } \\
\quad \text { level } \\
\text { measured } \\
\text { (mm-dd-yy) }\end{array}$ & $\begin{array}{l}\text { Reported depth } \\
\text { to water- } \\
\text { bearing zones } \\
\text { (feet below } \\
\text { land surface) }\end{array}$ & $\begin{array}{l}\text { Depth to } \\
\text { bedrock } \\
\text { (feet } \\
\text { below } \\
\text { land } \\
\text { surface) }\end{array}$ & $\begin{array}{c}\text { Water } \\
\text { use }\end{array}$ \\
\hline AD-679 & PMW-16A & 51 & $30-$ & $<0.5$ & -- & 17.60 & 03-08-99 & -- & 6 & $M$ \\
\hline AD-680 & PMW-16B & 181 & $158-\quad 178$ & 1.5 & -- & 25.00 & 03-08-99 & $\begin{array}{l}11,62,143, \\
180\end{array}$ & 4 & M \\
\hline AD-681 & PMW-17 & 200 & $180-$ & 0 & -- & 28.39 & 03-08-99 & -- & 12 & M \\
\hline AD-682 & PMW-20A & 99.7 & $79.7-99.7$ & .5 & -- & 20.35 & 03-08-99 & -- & 1.5 & $M$ \\
\hline AD-683 & EW-1 & 60 & $40-\quad 60$ & 2.1 & -- & 50.72 & 03-08-99 & -- & 10 & $E$ \\
\hline AD-684 & PMW-20B & 300 & $280-300$ & $>40$ & -- & 19.41 & 03-08-99 & -- & 2 & $M$ \\
\hline AD-685 & PMW-21A & 125 & $104.9-124.9$ & 3 & -- & 26.72 & 03-08-99 & 111 & 3 & M \\
\hline AD-686 & PMW-22A & 222 & $202-\quad 222$ & 15 & -- & 18.85 & 03-08-99 & 210 & 1.5 & M \\
\hline AD-687 & PMW-23 & 40 & $25-$ & .9 & -- & 7.84 & 03-08-99 & -- & 4 & $M$ \\
\hline AD-688 & EW-4 & 162 & $139.8-159.8$ & 13 & -- & $>71.21$ & 03-08-99 & $31,38,144$ & 6.5 & $\mathrm{E}$ \\
\hline AD-689 & PMW-21B & 266.5 & $246.5-266.5$ & 100 & -- & 23.99 & 03-08-99 & -- & 2 & M \\
\hline AD-690 & PMW-22B & 298 & $278-\quad 298$ & 21 & -- & 19.22 & 03-08-99 & -- & 4 & $M$ \\
\hline AD-691 & PMW-14 & 175 & $155-\quad 175$ & $<.5$ & -- & 15.18 & 03-08-99 & -- & 6 & $M$ \\
\hline AD-692 & EW-3 & 38 & $18-$ & 1 & -- & 23.74 & 03-08-99 & 31 & 5 & $E$ \\
\hline AD-693 & -- & 104 & $40-\quad 104$ & 7 & -- & -- & -- & -- & 23 & D \\
\hline AD-694 & -- & 153 & $25-\quad 153$ & 20 & -- & -- & -- & 148 & 8 & $\mathrm{D}$ \\
\hline AD-695 & PMW-25 & 90 & $70-$ & 6 & -- & 11.38 & 03-08-99 & 77 & 2 & $M$ \\
\hline AD-696 & PMW-25A & 195 & $175-195$ & 22 & -- & 14.41 & 03-08-99 & $\begin{array}{l}48,80,161 \\
181,195\end{array}$ & 2 & $M$ \\
\hline AD-697 & PMW-25B & 280 & $260-$ & 40 & -- & 12.23 & 03-08-99 & $\begin{array}{l}51,115,187, \\
232\end{array}$ & 2 & $M$ \\
\hline AD-704 & -- & 85 & $40-$ & 15 & -- & -- & -- & -- & -- & $D$ \\
\hline AD-705 & -- & 105 & -- & -- & -- & -- & -- & -- & -- & $D$ \\
\hline AD-710 & OW-1 & 214.9 & $193-$ & 15 & -- & 16.29 & 03-08-99 & 43,70 & 3 & $M$ \\
\hline AD-711 & OW-2 & 195 & $170-$ & 6 & -- & 10.19 & 03-08-99 & 95,174 & 4 & $M$ \\
\hline AD-712 & EW-5 & 215 & 190 - & 20 & 0.1 & 47.49 & 03-08-99 & 36,159 & .5 & $E$ \\
\hline AD-713 & EW-6 & 164.5 & $140-$ & $>100$ & -- & 22.70 & 03-08-99 & $\begin{array}{l}74,101,117 \\
151\end{array}$ & 3 & $E$ \\
\hline AD-714 & EW-7 & 206 & $189-$ & $>50$ & -- & 27.69 & 03-08-99 & 133,198 & 2 & $E$ \\
\hline AD-715 & PMW-3C & 320.6 & $298-$ & $>35$ & -- & 28.43 & 03-08-99 & $\begin{array}{l}51,90,99,157 \\
161,260,306, \\
308\end{array}$ & 2.5 & M \\
\hline AD-716 & PMW-3D & 465.5 & $455-$ & 60 & -- & 27.27 & 03-08-99 & $156,342,461$ & 2 & $M$ \\
\hline
\end{tabular}




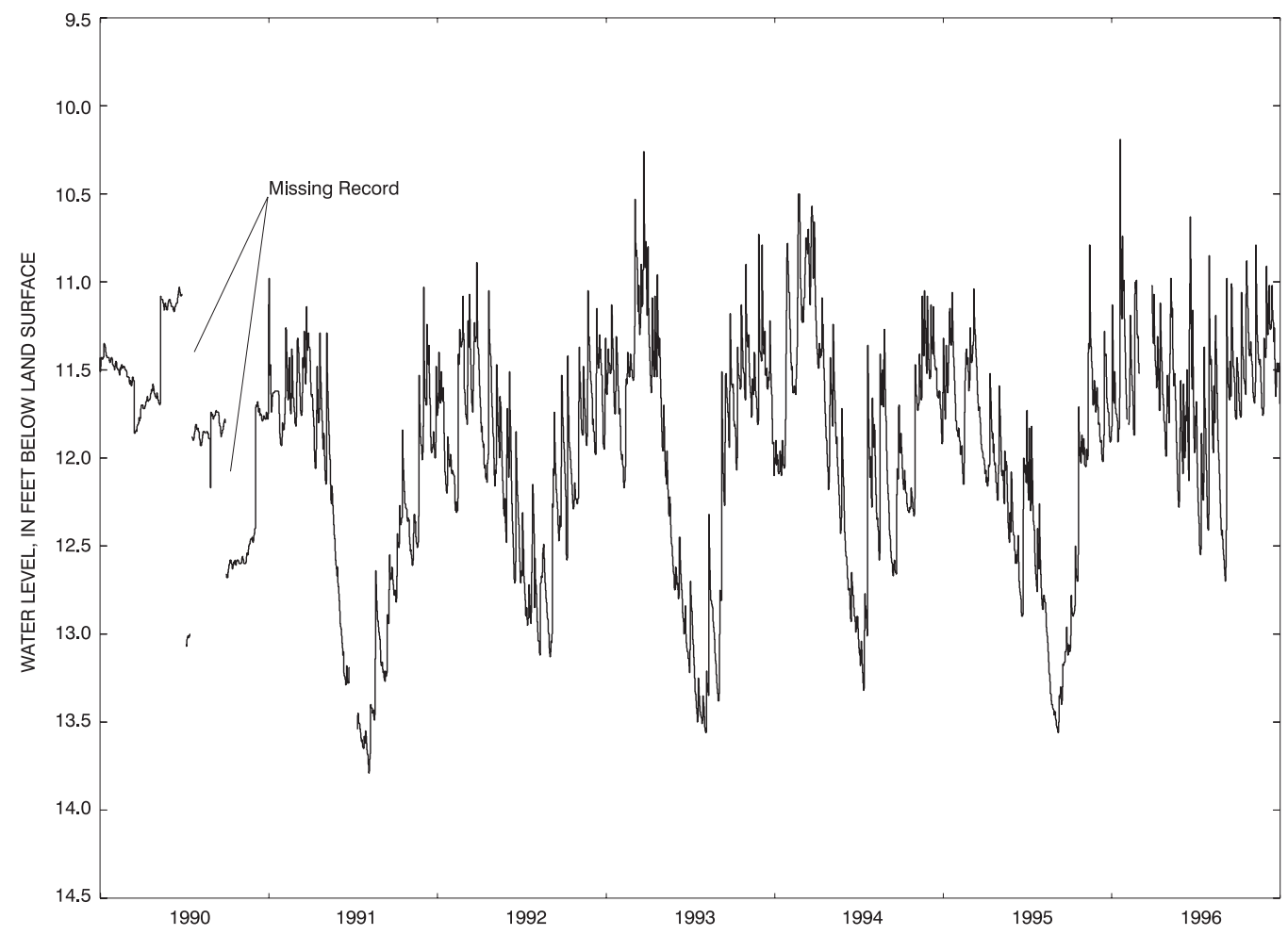

Figure 4. Hydrograph of observation well AD-146, near York Springs, Adams County, Pennsylvania (1990-96).

The short-term responses to precipitation and changes in discharge rates of the extraction system of selected wells are shown in figure 5. In all of the wells, the response to precipitation is rapid (within a few hours of rainfall) and generally is followed by a slow but continuous rise in water levels for the next day or so. Eventually, the water level begins a gradual decline until the next precipitation event. Decreases in the discharge of the extraction wells or a shut down of the extraction system also results in a rapid rise in water levels. This response, however, is generally less or absent in wells AD-657, AD-670, AD-676, and AD-671.

\section{Ground-Water Flow}

Under nonpumping conditions, the hydraulic gradient in the vicinity of the Elevator Site is from west to east (fig. 6). Gradients are steeper west of the Elevator Site than east of the Elevator Site. A small pond in the offsite area east of the Elevator Site may be a minor source of recharge to the bedrock zone. In the bedrock zone, the hydraulic gradient is approximately $0.02 \mathrm{ft} / \mathrm{ft}$ (Rizzo Associates, 1991).

Utilizing measured water levels in monitor wells and the depths of on switches for pumps in the extraction wells, Cummings/Riter (1998, figs. 4-2 and 4-3) evaluated the capture zones created by the current extraction system, which is composed of extraction wells AD-683, AD-692, AD-656, AD-688, AD-712, AD-713, and AD-714 (table 1). Cones of depression created by shallow extraction wells AD-683 and AD-692 are small and have only a minor effect on the potentiometric surface. Cones of depression created by the deeper extraction wells are considerably larger than those of the shallow extraction wells and are elongated parallel to strike (N. $23^{\circ}$ E.). Anisotropy is more evident for the onsite extraction wells 


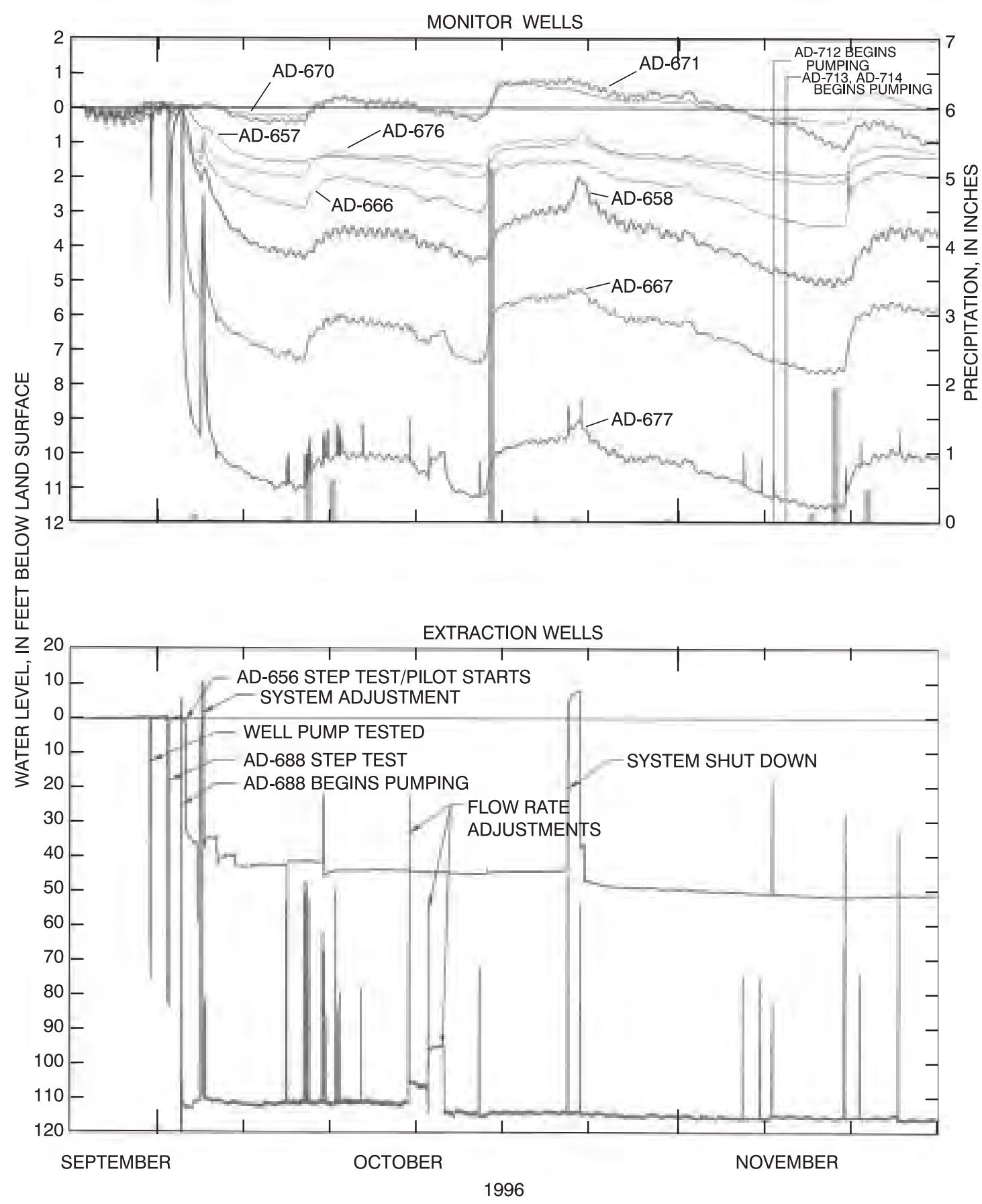

Figure 5. Short-term responses to precipitation and changes in discharge rates of the extraction system at selected wells, Gettysburg Elevator Plant Superfund Site, Gettysburg, Pennsylvania (modified from Cummings/Riter, 1997, fig. 3-6). 


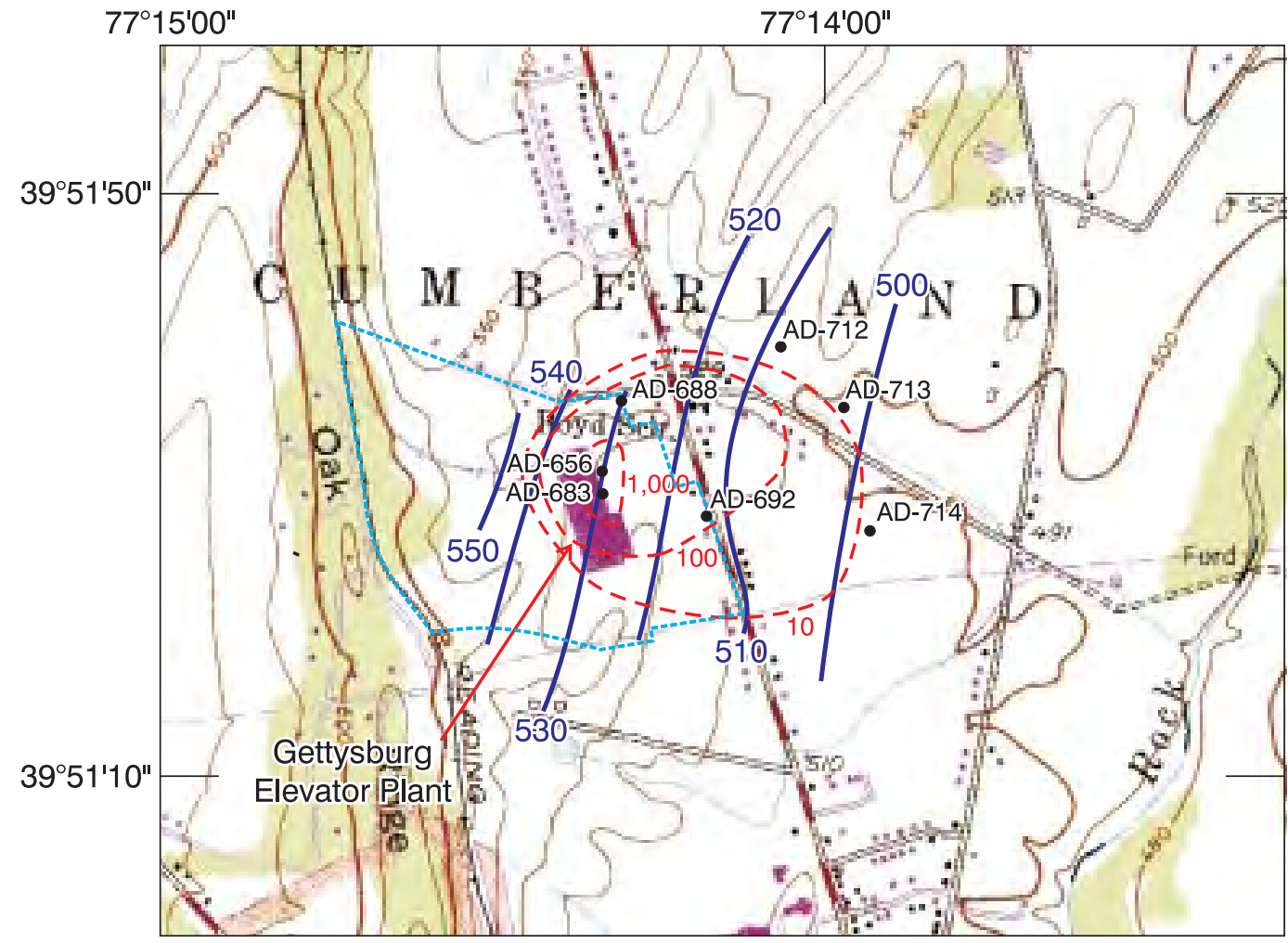

Base from U.S. Geological Survey Gettysburg 1:24,000 1981

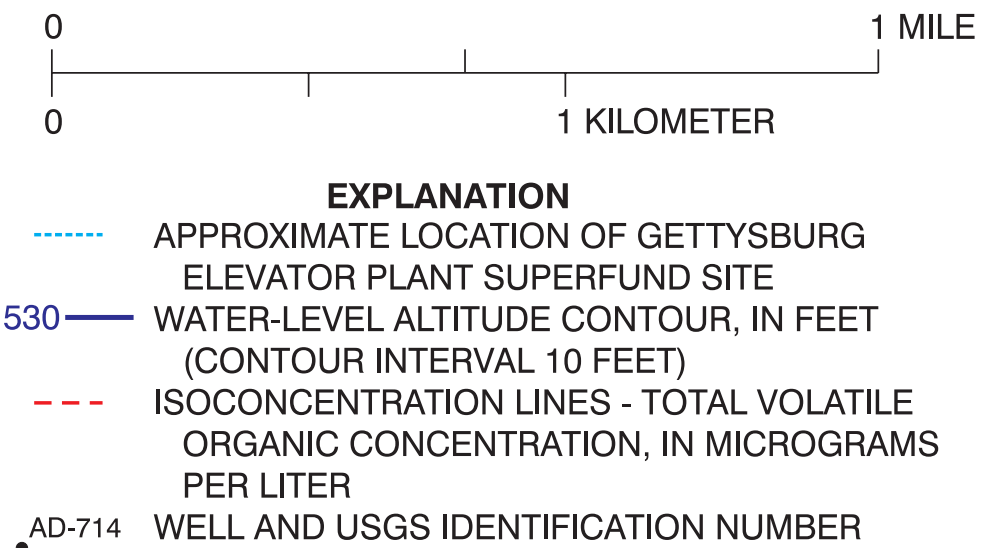

Figure 6. Potentiometric surface and isoconcentration lines showing total volatile organic concentration in the bedrock zone, October 1, 1996, Gettysburg Elevator Plant Superfund Site, Gettysburg, Pennsylvania (modified from Cummings/Riter, 1998, figs. 3-2 and 3-5). 
AD-656 and AD-688 than for the offsite wells AD-712, AD-713, and AD-714. This anisotropy suggests that heterogeneity in the unweathered bedrock, which creates the anisotropy, may be more prevalent in the Heidlersburg Member of the Gettysburg Formation than in the upper part of the Gettysburg Formation.

Cummings/Riter $(1997 ; 1998)$ also created isoconcentration maps for total VOC's under nonpumping conditions (fig. 6). In the bedrock zone, ground-water flow in the direction perpendicular to dip is impeded relative to flow along strike. Because of this anisotropy, ground-water-flow directions are not necessarily perpendicular to lines of equal hydraulic head, and ground-water-flow directions will be offset toward the strike direction. This anisotropy has resulted in a diffused contaminant plume (fig. 6) that is elongated not only perpendicular (eastward) but also parallel to the strike direction (Cummings/Riter, 1998; fig. 3-2).

The depth and vertical direction of ground-water flow can sometimes be determined from geophysical logs, flowmetering, or brine tracing. Geophysical logs and brine-tracing measurements collected by the USGS indicate water enters the borehole of well AD-343 (fig. 1) through a number of indeterminate fractures at 371-386 ft bls and moves upward. In well AD-591, however, the geophysical logs and brine tracing indicate areas of no flow and minor downward vertical flow in the borehole at depths of 300, 600, and $800 \mathrm{ft}$ (table 2). Cummings/Riter (1995; 1996) conducted brine tracing in four wells (AD-684, AD-689, AD-690, AD-697), and heatpulse flowmetering in three wells (AD-712, AD-713, AD-714). Under ambient conditions the geophysical logs indicated the direction of vertical flow was downward in five of the seven wells; upward and downward vertical flow was indicated in two other wells (table 2). Cummings / Riter (1996) also utilized fluid-resistivity and fluid-temperature logs to identify the presence of vertical flow in the boreholes of wells AD-688, AD-710, and AD-711. However, water levels in two monitor wells, AD-664 and AD-665 (fig. 2), indicate an upward vertical flow gradient. Both wells are located along a fracture trending N. $43^{\circ}$ E. (Rizzo Associates, 1991), and well AD-665 has been observed to occasionally flow at the surface.

\section{Aquifer Properties}

Hydraulic conductivity, transmissivity, and storage are aquifer properties that may vary spatially because of geologic heterogeneity. Estimation of these properties allows quantitative determination of the hydraulic response of the aquifer to recharge and pumping. Hydraulic conductivity is defined as the volume of water that will move in a unit time under a unit hydraulic gradient through a unit area, at the prevailing temperature (Heath, 1983, p. 12). Transmissivity, the hydraulic conductivity multiplied by the saturated thickness of the aquifer, represents a vertical average of hydraulic conductivities that may vary with depth. The storage coefficient (storativity) is the volume of water released from or taken into storage by an aquifer per unit surface area per unit change in head (Heath, 1983, p. 28). Storage coefficients are important for understanding hydraulic response to transient stresses on aquifers. These properties can be estimated on a scale of a few 10's to 100's of feet by analysis of data from packer tests, single- or multiplewell aquifer tests, or on a scale of 1,000's of feet to miles by numerical methods such as simulation of ground-water flow by use of a computer-based model. Most analytical techniques used to estimate the hydraulic properties of aquifers were developed for porous media, such as unconsolidated sediments. These techniques, however, may provide reasonable estimates of aquifer properties in fractured rocks. 
Table 2. Summary of vertical borehole measurements in the vicinity of the Gettysburg Elevator Plant Superfund Site, Gettysburg, Pennsylvania (Brine tracing has a flow rate detection limit of about 0.5 gallons per minute; however, a general direction of flow may be indicated at flow rates as low as 0.2 gallons per minute)

[--, not applicable]

\begin{tabular}{|c|c|c|c|c|}
\hline Well number & $\begin{array}{l}\text { Method used in } \\
\text { determining } \\
\text { vertical flow }\end{array}$ & $\begin{array}{c}\text { Depth } \\
\text { (feet below } \\
\text { land surface) }\end{array}$ & $\begin{array}{l}\text { Flow rate under } \\
\text { ambient conditions } \\
\text { (gallons per minute) }\end{array}$ & $\begin{array}{l}\text { Flow direction under } \\
\text { ambient conditions }\end{array}$ \\
\hline AD-343 & Brine tracing & 80 & no flow & -- \\
\hline AD-343 & Brine tracing & 160 & no flow & -- \\
\hline AD-343 & Brine tracing & 220 & no flow & - \\
\hline AD-343 & Brine tracing & 320 & 2.5 & up \\
\hline AD-591 & Brine tracing & 100 & no flow & - \\
\hline AD-591 & Brine tracing & 160 & no flow & - \\
\hline AD-591 & Brine tracing & 300 & .5 & down \\
\hline AD-591 & Brine tracing & 360 & no flow & -- \\
\hline AD-591 & Brine tracing & 600 & below detection limit & down? \\
\hline AD-591 & Brine tracing & 800 & below detection limit & down? \\
\hline AD-684 & Brine tracing & 70 & no flow & -- \\
\hline AD-684 & Brine tracing & 110 & below detection limit & down? \\
\hline AD-684 & Brine tracing & 270 & below detection limit & up? \\
\hline AD-689 & Brine tracing & 90 & below detection limit & down? \\
\hline AD-689 & Brine tracing & 160 & no flow & - \\
\hline AD-690 & Brine tracing & 150 & below detection limit & down? \\
\hline AD-690 & Brine tracing & 235 & no flow & - \\
\hline AD-690 & Brine tracing & 265 & 2.2 & up \\
\hline AD-697 & Brine tracing & 70 & no flow & -- \\
\hline AD-697 & Brine tracing & 150 & no flow & - \\
\hline AD-697 & Brine tracing & 210 & below detection limit & down? \\
\hline AD-697 & Brine tracing & 230 & no flow & - \\
\hline AD-712 & Heatpulse & 70 & .02 & down \\
\hline AD-712 & Heatpulse & 123 & .07 & down \\
\hline AD-712 & Heatpulse & 180 & .03 & down \\
\hline AD-713 & Heatpulse & 83 & .005 & down \\
\hline AD-713 & Heatpulse & 114 & .005 & down \\
\hline AD-713 & Heatpulse & 146 & .005 & down \\
\hline AD-713 & Heatpulse & 176 & .005 & down \\
\hline AD-714 & Heatpulse & 99 & .02 & down \\
\hline AD-714 & Heatpulse & 150 & .04 & down \\
\hline AD-714 & Heatpulse & 190 & .04 & down \\
\hline
\end{tabular}




\section{Packer Tests}

Water enters open-hole wells through discrete secondary openings (joints, fractures, faults, bedding planes or bedding partings) in bedrock aquifers. Most ground-water flow and contaminant movement at the site is through one or more of these secondary openings. The hydraulic and chemical characteristics of each discrete secondary opening can differ, especially vertically. By isolating discrete secondary openings with inflatable packers, hydraulic properties of these secondary openings and the extent of vertical hydraulic connection between secondary openings can be determined. This determination provides data on the vertical distribution of aquifer properties.

Rizzo Associates (1991) performed packer tests in seven monitor wells ranging in depth from 60 to $245 \mathrm{ft}$ to determine the hydraulic conductivity of bedrock in the open borehole (table 3 ). In general, results of packer tests indicated (1) hydraulic conductivities tended to decrease with increasing depth, (2) discrete secondary openings are not well connected in the vertical direction, and (3) there were no noticeable correlations between fracture spacings.

Table 3. Estimates of hydraulic conductivity from packer tests by Rizzo Associates, 1991 (figs. 3-15, 3-16, 3-17), in seven monitor wells at the Gettysburg Elevator Plant Superfund Site, Gettysburg, Pennsylvania

[Hydraulic conductivity in feet per day; ft bls, feet below land surface; <, less than]

\begin{tabular}{|c|c|c|c|c|c|c|}
\hline \multirow{2}{*}{ Well number } & \multicolumn{4}{|c|}{ Hydraulic conductivity } & \multirow{2}{*}{$\begin{array}{c}\text { Number of } \\
\text { packed zones }\end{array}$} & \multirow{2}{*}{$\begin{array}{l}\text { Depth range } \\
\text { of packed } \\
\text { zone (ft bls) }\end{array}$} \\
\hline & Minimum & Median & Mean & Maximum & & \\
\hline AD-655 & 0.00028 & 0.0061 & 0.0061 & 1.3 & 8 & 113 to 193 \\
\hline AD-662 & $<.017$ & $<.017$ & .095 & .60 & 17 & 105 to 200 \\
\hline AD-663 & .009 & $<.017$ & $<.017$ & $<.017$ & 17 & 107 to 197 \\
\hline AD-664 & $<.017$ & .060 & .31 & 1.1 & 10 & 24 to 80 \\
\hline AD-668 & $<.017$ & $<.017$ & .024 & .055 & 6 & 26 to 60 \\
\hline AD-669 & $<.017$ & $<.017$ & $<.017$ & .018 & 12 & 131 to 197 \\
\hline AD-671 & $<.017$ & $<.017$ & .31 & 4.2 & 42 & 9 to 245 \\
\hline
\end{tabular}

Cummings/Riter (1996) performed packer tests in two extraction wells-AD-712 and AD-713. These packer tests were designed to evaluate proposed screened intervals in extraction well installation (table 1) and to determine if the extraction wells were in hydraulic communication with one or more monitor wells. Pumping of well AD-712 resulted in a drawdown of $3.13 \mathrm{ft}$ in monitor well AD-680. Pumping well AD-713 resulted in a drawdown in the packed zones and in monitor wells AD-685, AD-689, AD-695, AD-696, and AD-697.

\section{Aquifer Tests}

Multiple-well aquifer tests (single pumping well and multiple observation wells) were conducted by Rizzo Associates (1991) and Cummings/Riter (1997) for the RI and during the final implementation of the pump-and-treat system for site remediation. The aquifer tests performed by Rizzo Associates (1991) utilized wells AD-654 and AD-655 as the pumping wells; Cummings/Riter (1997) utilized wells AD-656, AD-683, AD-688, AD-692, AD-712, AD-713, and AD-714 as the pumping wells.

Well AD-654 was pumped at a constant discharge rate of $0.5 \mathrm{gal} / \mathrm{min}$ for 24 hours. Drawdowns were measured in a number of shallow and deep wells. The maximum drawdowns reported for the pumping and monitor wells are presented in table 4. 
Table 4. Reported maximum drawdowns at selected monitor wells during the 24-hour constant rate discharge tests of wells AD-654 and AD-655 (modified from Rizzo Associates, 1991) at the Gettysburg Elevator Plant Superfund Site, Gettysburg, Pennsylvania

[gal/min, gallons per minute; --, not measured ]

\begin{tabular}{|c|c|c|c|c|c|c|c|}
\hline \multicolumn{4}{|c|}{$\begin{array}{l}\text { Pumping well AD-654 } \\
\text { (discharge }=0.5 \mathrm{gal} / \mathrm{min} \text { ) }\end{array}$} & \multicolumn{4}{|c|}{$\begin{array}{l}\text { Pumping well AD-655 } \\
\text { (discharge }=8.5 \mathrm{gal} / \mathrm{min} \text { ) }\end{array}$} \\
\hline Well number & $\begin{array}{l}\text { Drawdown } \\
\text { (feet) }\end{array}$ & Well number & $\begin{array}{l}\text { Drawdown } \\
\text { (feet) }\end{array}$ & Well number & $\begin{array}{l}\text { Drawdown } \\
\text { (feet) }\end{array}$ & Well number & $\begin{array}{l}\text { Drawdown } \\
\text { (feet) }\end{array}$ \\
\hline AD-654 & 10.53 & AD-669 & 0.16 & AD-654 & 4.44 & AD-669 & 24.19 \\
\hline AD-655 & .26 & AD-670 & .28 & AD-655 & 95.20 & AD-670 & .31 \\
\hline AD-657 & .14 & AD-671 & .04 & AD-657 & 1.14 & AD-671 & .22 \\
\hline AD-658 & .16 & AD-672 & -.17 & AD-658 & 12.69 & AD-672 & .55 \\
\hline AD-659 & .05 & AD-673 & .09 & AD-659 & .21 & AD-673 & 11.34 \\
\hline AD-660 & .11 & AD-674 & .43 & AD-660 & .26 & AD-674 & .39 \\
\hline AD-661 & .33 & AD-675 & .33 & AD-661 & 1.53 & AD-675 & .29 \\
\hline AD-662 & .56 & AD-676 & .12 & AD-662 & 5.31 & AD-676 & .95 \\
\hline AD-663 & -- & AD-677 & .12 & AD-663 & .22 & AD-677 & 2.21 \\
\hline AD-664 & .16 & AD-678 & .10 & AD-664 & .22 & AD-678 & .13 \\
\hline AD-665 & .17 & AD-679 & -- & AD-665 & .32 & AD-679 & .54 \\
\hline AD-666 & .04 & AD-680 & -- & AD-666 & 1.48 & AD-680 & .14 \\
\hline AD-667 & .10 & AD-681 & -- & AD-667 & 1.72 & AD-681 & 1.55 \\
\hline AD-668 & .53 & AD-691 & -- & AD-668 & 2.96 & AD-691 & .09 \\
\hline
\end{tabular}

Analysis of the drawdown data from pumping of well AD-654 (table 4) indicates the bedrock zone is comprised of dipping stratigraphic beds with differing hydraulic conductivities. For example, well AD-662, located approximately 1,600 ft west and downdip of AD-654, exhibited a drawdown of $0.56 \mathrm{ft}$ (table 4 and fig. 1). This is greater than the drawdowns measured in wells AD-669 (0.16 ft) and AD-655 $(0.26 \mathrm{ft})$, which are located in closer proximity to pumping well AD-654. Based upon a strike of about N. $23^{\circ}$ E. and a dip of about $23^{\circ}$ NW., monitor well AD-662 is screened in the same bed as pumping well AD-654. Monitor wells AD-669 and AD-655, however, are screened stratigraphically lower than the pumping well. The smaller drawdown measured in monitor wells AD-669 and AD-655 is the result of an intervening bed with considerably lower hydraulic conductivity than the one in which monitor well AD-662 and pumping well AD-654 are screened in.

Analysis of the drawdown data from pumping of well AD-655 (table 4) shows a similar pattern. Drawdowns measured in monitor wells AD-658 (12.69 ft), AD-669 $(24.19 \mathrm{ft})$, and AD-673 $(11.34 \mathrm{ft})$ are considerably greater than the drawdowns in monitor wells AD-657 $(1.14 \mathrm{ft})$, AD-668 $(2.96 \mathrm{ft})$, and AD-672 $(0.55 \mathrm{ft})$. Although all six monitor wells are located parallel to strike, the reason for the difference in measured drawdowns is related to the stratigraphic position of the well screen. Monitor wells AD-658, AD-669, and AD-673 are screened in the same bed as the pumping well AD-655. Monitor wells AD-657, AD-668, and AD-672 are screened in a stratigraphically higher bed. The intervening bed has a lower hydraulic conductivity than the bed in which the pumping well is screened in. The lower hydraulic conductivity prevents the stress (drawdown) from being easily transmitted to wells AD-657, AD-668, and AD-672.

Multiple-well aquifer tests were conducted by Cummings/Riter (1997) in the fall of 1996 to evaluate the newly completed onsite and offsite extraction systems. Estimates of transmissivity and storage coefficient are presented in table 5. 
Table 5. Estimates of transmissivity and storage coefficient during the 1996 implementation of the existing ground-water extraction system at the Gettysburg Elevator Plant Superfund Site, Gettysburg, Pennsylvania (from Cummings/Riter, 1997)

$\left[\mathrm{ft}^{2} / \mathrm{d}\right.$, feet squared per day]

\begin{tabular}{cccc}
\hline Extraction well number & $\begin{array}{c}\text { Monitor well } \\
\text { number }\end{array}$ & $\begin{array}{c}\text { Transmissivity } \\
\left(\mathrm{ft}^{2} / \mathrm{d}\right)\end{array}$ & $\begin{array}{c}\text { Storage coefficient } \\
\text { (dimensionless) }\end{array}$ \\
\hline AD-656 & AD-657 & 59 & 0.022 \\
AD-688 & AD-658 & 250 & .00009 \\
AD-688 & AD-666 & 150 to 300 & 0.000076 to 0.00014 \\
AD-688 & AD-667 & 101 & .000031 \\
AD-688 & AD-676 & 170 & .015 \\
AD-688 & AD-677 & 86 to 97 & 0.000082 to 0.000063 \\
AD-712 & AD-690 & 95 & .00005 \\
AD-713 & AD-697 & 95 & .00002 \\
\hline
\end{tabular}

\section{SIMULATION OF GROUND-WATER FLOW}

Four, three-dimensional quasi-finite-difference numerical models were prepared by the USGS for the Elevator Site. MODFLOW (McDonald and Harbaugh, 1988; Harbaugh and McDonald, 1996) was used to simulate regional steady-state and transient flow and the areas that contribute recharge to the seven extraction wells that comprise the current extraction system in each model. Ground-water-flow pathlines from the output of the flow models were calculated and displayed utilizing MODPATH (Pollock, 1994), a particle-tracking module linked to MODFLOW.

Three ground-water-flow models were completed in 1997 but were not calibrated (D.J. Low and D.J. Goode, U.S. Geological Survey, written commun., 1997). These three models simulated the ground-waterflow system as isotropic and homogeneous, anisotropic and homogeneous, and isotropic and heterogeneous. These three noncalibrated models were used to evaluate (1) a hypothesized stagnation zone created by pumping offsite and onsite extraction wells and (2) the size and extent of the offsite and onsite capture zones. The results indicated the need for a calibrated model. The fourth model, which is described in the following sections, was calibrated by use of an automatic, nonlinear optimization program, MODFLOWP (Hill, 1992), that minimizes the differences between measured and simulated water levels.

\section{Model Structure and Assumptions}

The model structure is based on a simplified conceptualization of the ground-water-flow system. The shallow and bedrock zones are modeled as equivalent porous media, such as unconsolidated granular deposits. Thus, it is assumed that ground-water flow can be described by use of a three-dimensional flow equation based on Darcy's Law. In this approach, the hydraulic conductivities used in the model represent the bulk properties of the bedrock zone. Water flux, which may pass through only a small fraction of the rock mass occupied by secondary openings, is simulated as distributed throughout the bedrock zone. In the vicinity of the Gettysburg Elevator Plant, ground-water flow in secondary openings is simulated as occurring in dipping, stratigraphic beds of high hydraulic conductivity that are separated by dipping beds of low hydraulic conductivity. Detailed characteristics of flow within the secondary openings at scales of feet or less are not accurately simulated in the model.

The model grid is aligned parallel to strike (N. $23^{\circ}$ E.) and corresponds to the assumed major axis of large-scale anisotropy of horizontal hydraulic conductivity (fig. 6). The assumed minor axis of anisotropy, therefore, is oriented in the dip direction. Cell dimensions of the horizontal model grid range from $328 \mathrm{ft}$ 
by $328 \mathrm{ft}$ on the edge of the model domain to $66 \mathrm{ft}$ by $66 \mathrm{ft}$ in the location of site extraction wells. The total area of active model cells is about $2.3 \mathrm{mi}^{2}$. Lateral boundaries of the model are defined as no-flow (zeroflux) cells or head-dependent flux (stream) cells. The no-flow boundary conditions were specified along topographic divides that are assumed to be ground-water divides (fig. 7). The western model boundary is underlain by a diabase dike that limits ground-water flow (fig. 1). No-flow boundaries on topographic divides at the northern and southern ends of the model area are sufficiently far from the area of interest that the precise location of the ground-water divide will not have much effect on model results. Stream

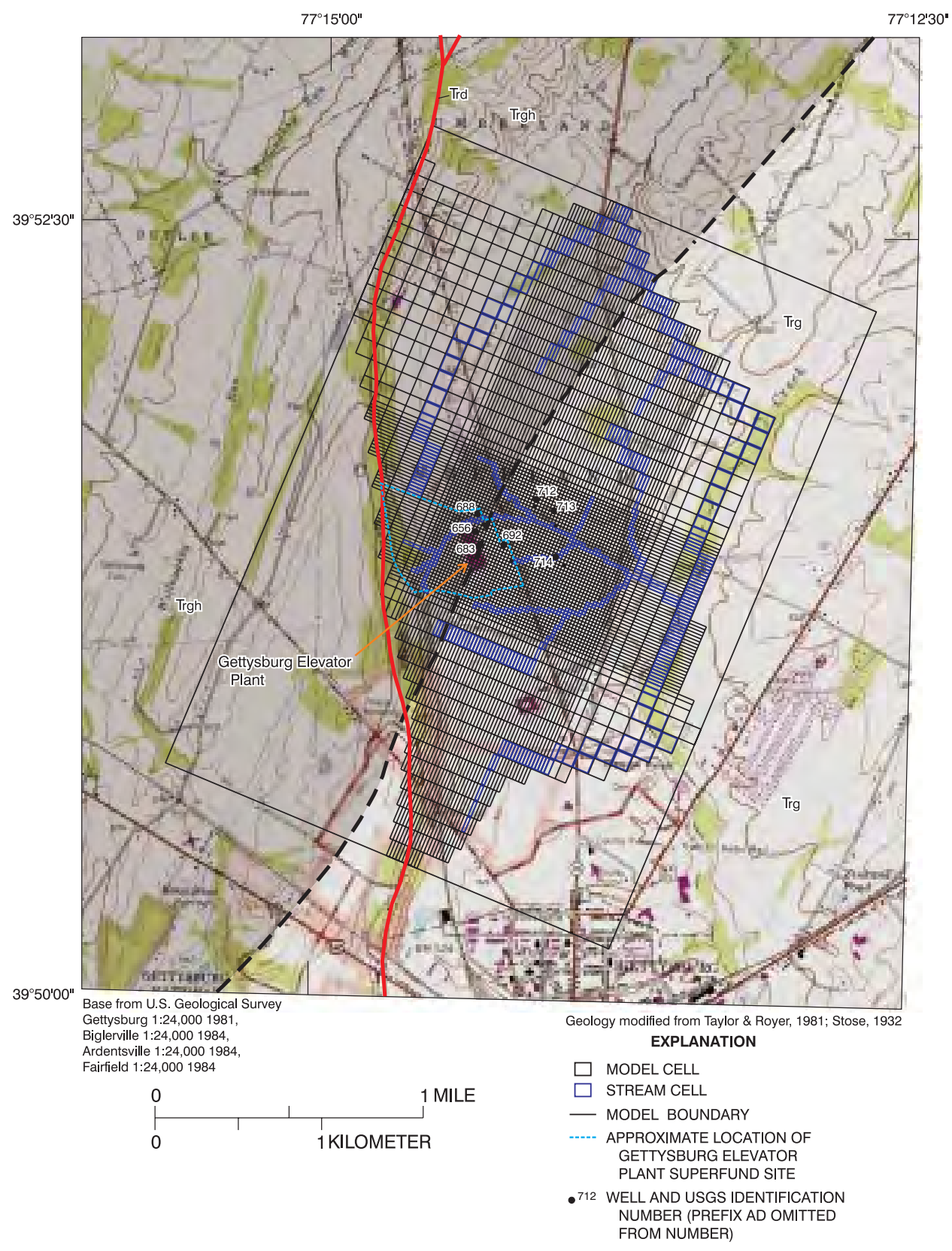

Figure 7. Model grid, boundaries, stream cells, and locations of extraction wells at the Gettysburg Elevator Plant Superfund Site, Gettysburg, Pennsylvania. 
cells represent Rock Creek and its tributaries within the modeled area. Previous studies and measured water levels indicate that Rock Creek is a regional drain for the ground-water system and underflow does not result. The bottom of the model also was defined as a no-flow boundary. A constant-flux boundary was defined at the top of the model where the fluxes equal the effective areal recharge.

The 511-ft thickness of the dipping beds that compose the ground-water system are represented in the model by 16 layers (fig. 8). The altitude of the top surface of the model was derived from digitized land-surface elevation contours with 20-ft contour intervals outside the Gettysburg Elevator Plant Site property and with 5-ft contour intervals (Cummings/Riter, written commun., 1999) within Gettysburg Elevator Plant Site property.

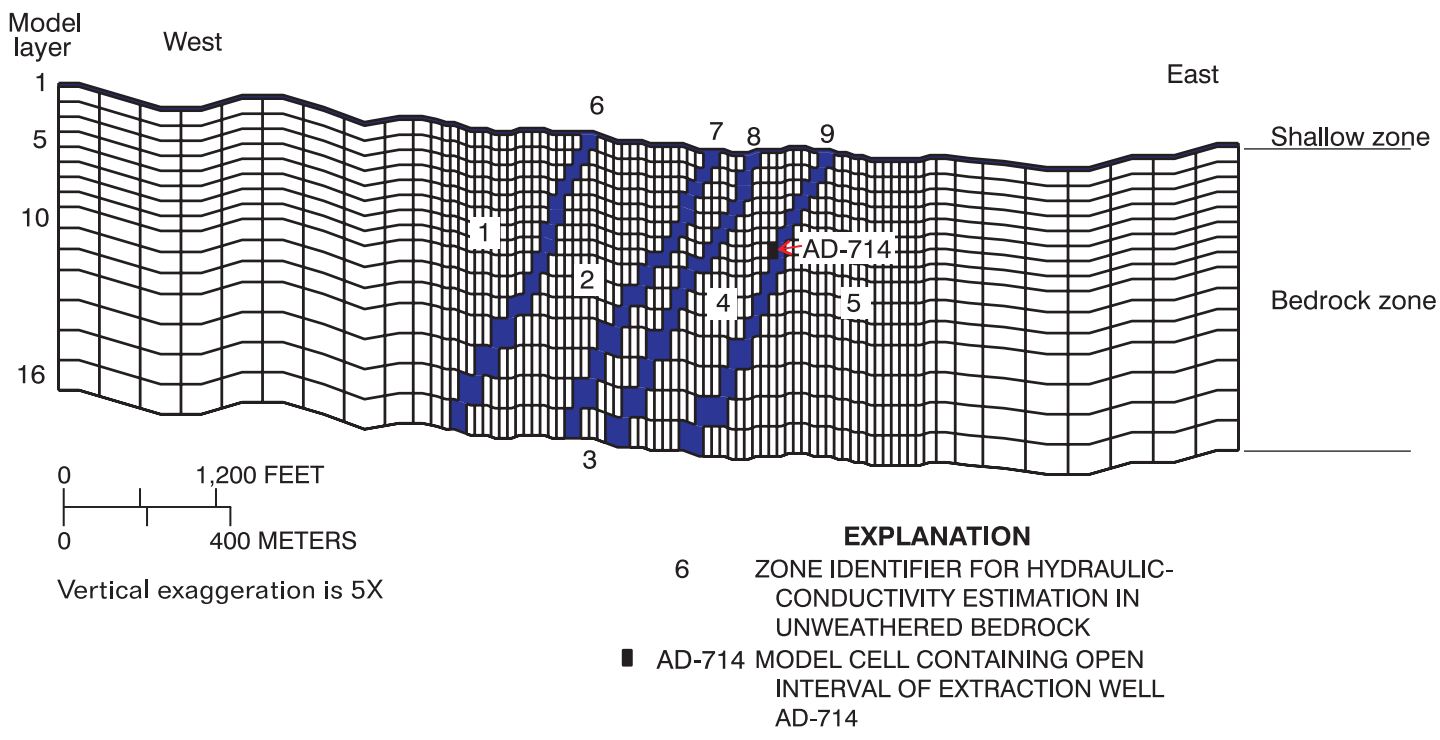

Figure 8. Schematic cross-section of model structure showing thickness of 16 layers and vertical discretization of dipping beds with high (zones 6, 7, 8, and 9) and low hydraulic conductivities (zones 1, 2, 3, 4, and 5), Gettysburg Elevator Plant Superfund Site, Gettysburg, Pennsylvania. (Please note that zones 1-9 represent the high- and low-permeability beds in the model area and should not be confused with the terms shallow and bedrock zones as defined in this report.)

The shallow zone is represented by model layer 1 and is uniformly 6-ft thick. The use of a relatively thin upper layer was deemed to be acceptable on the basis of the following observations: (1) the average driller reported depth to bedrock for all of the monitor and extraction wells at the Elevator Site is $6 \mathrm{ft}$ (table 1); (2) the shallowest water-bearing interval was penetrated at a depth of $6 \mathrm{ft}$ (table 1); (3) of 43 soil borings, 26 encountered bedrock at a depth of $6 \mathrm{ft}$ or less (Rizzo Associates, 1991, appendix C); and (4) streams at the Elevator Site are not deeply incised (bottom of channel is bedrock, height of stream bank rarely exceeds $3 \mathrm{ft})$.

The bedrock zone is represented by model layers 2 through 16; the thickness of the model layers increases from 25 to $50 \mathrm{ft}$ with depth. This configuration provide sufficient discretization to describe vertical flow in the units and to describe the geometry of the dipping beds without excessive computational times. Extraction wells, except for well AD-692, are open to dipping stratigraphic beds that have high hydraulic conductivities that extend along strike and dip throughout the model area. The dipping, dark layers (identified as zones 6, 7, 8, and 9 in the model (fig. 8)) represent dipping beds with 
discrete secondary openings. These beds have been identified by Rizzo Associates (1991) and Cummings/Riter (1995) to have relatively higher hydraulic conductivities than the surrounding beds. The vertical position of each bed depends on the dip and strike and the land-surface altitude. Hence, these pumped beds are represented by stair-step configurations of high hydraulic-conductivity cells occurring in model layers 2 through 16 (fig. 8). Development of the model input files and computations associated with locating the dipping beds in the three-dimensional model grid are by the preprocessor using a programmed Graphical-User Interface (Shapiro and others, 1997; Winston, 1999).

In the model, the vertical hydraulic conductivity is assumed to be equal to the horizontal hydraulic conductivity. This assumption was required because vertical flow is controlled by a network of secondary openings that range from a few feet to $10 \mathrm{ft}$ or so in length and could not be simulated in the model.

The entire thickness of each model layer is assumed to be saturated. This assumption means that the transmissivity ( $\mathrm{T}$ ) of the top model layer (layer 1) is assumed to be independent of the computed water level. This assumption is required in MODFLOWP simulation. The model results are relatively insensitive to minor changes in the transmissivity of the top layer because most flow is in the lower bedrock model layers. Rapid drawdown observed during pumping in the bedrock zone indicates that the storage coefficient is very small, and the system can be reasonably approximated as confined.

Initial transmissivity estimates were determined from analyses of aquifer tests (table 5) at the Elevator Site (Rizzo Associates, 1991; Cummings/Riter, 1997). Analysis of packer tests in seven wells (table 3) provided estimates of horizontal hydraulic conductivity. Although a number of water-bearing intervals (table 1) are known to be present at depths greater than the bottom layer of the model (layer 16), the model required that the hydraulic conductivity be set to zero below the bottom of the deepest model layer. This assumption was deemed appropriate and is based on the following: (1) the depth of the deepest monitor well at the site, well AD-716 (465.5 ft), is included within layer 16 of the model, and (2) the depth of the deepest extraction well, AD-712 (215 ft), is almost $300 \mathrm{ft}$ higher than the bottom of the deepest model layer.

The components of the budget for the ground-water system that are included in the model are (1) uniform recharge to the water table, (2) discharge to extraction wells, and (3) discharge to and infiltration from streams. The steady-state assumption implies that these fluxes are in equilibrium and that water level is not changing in time. In reality, these fluxes, particularly pumping rates and recharge, are changing constantly, and water level changes in response to these fluctuations. The steady-state model corresponds to the average flow conditions and approximates the average fluxes and water level. Transient response to initial pumping of the extraction system is used in the model calibration. Simulations of contributing areas were made for long-term, average conditions, which are assumed to be at steady state for the simulation.

Recharge to the water table is assumed to be a spatially uniform rate of $7 \mathrm{in} / \mathrm{yr}$ (Taylor and Royer, 1981) because detailed spatial information on factors affecting infiltration are not available for the site. On average, recharge to the water table is precipitation minus surface runoff and evapotranspiration. Areal recharge enters through the top model layer.

The pumping rates used in the model (table 9) represent approximations of the long-term-average withdrawal rates for the extraction wells (Cummings/Riter, 1998, table 5-3; Cummings/Riter, oral commun., 2000). Wells AD-683 and AD-692 do not pump water on a continuous basis. Recharge to these two wells is limited and the pumps quickly (within a few minutes) lower the water level to sensors that signal the pumps to switch off. The water levels then rise until a second set of sensors are reached that turn the pumps on again; the sequence is then repeated. 
Streams are simulated in model layer 1 (shallow zone), and the aquifer discharges to the stream if the water level in a model cell is higher than the water level of the stream in that cell. Streamflow can enter the aquifer if the water level of the stream is higher than the head in the aquifer, provided the stream is flowing. Stream water levels are estimated from topographic maps.

\section{Calibration of Numerical Model}

The numerical model was calibrated by use of MODFLOWP (Hill, 1992), a parameter-estimation program that minimizes model error. Model error is defined as the sum of squared, weighted residuals, where residuals are the differences between measured and simulated water level (table 6). Forty-nine model cells correspond to locations where long-term average water levels and drawdown during 24 hours of pumping were estimated from previous studies (Rizzo Associates, 1991; Cummings/Riter, 1998).

The MODFLOWP program calculates optimum values of model parameters, such as storage coefficient and hydraulic conductivity, for a particular model structure. The model structure includes all quantitative information that establishes the functional relation between model parameters and simulated water levels. Although properties of model cells can be specified individually, the approach is to group cells with similar properties into zones with uniform parameters. Defining high and low hydraulicconductivity zones for model simulation appreciably reduces the number of model parameters and improves the reliability of parameter estimates. Nine zones (fig. 8) were determined on the basis of hydrogeologic information and in this model correspond to beds of alternating high (zones 6-9) and low hydraulic conductivity (zones 1-5).

Several model parameters were set at bounding values and were not identified by MODFLOWP. Storage coefficient values identified in preliminary calibrations were unrealistically low and were set at minimum values based on bed thickness, assumed fracture aperture, and water compressibility (table 7). Water levels and model error are relatively insensitive to storage coefficient values, when the values are less than 0.0001 . Hydraulic properties of the top model layer could not be calibrated because water level information is not available for depths of less than $6 \mathrm{ft}$. The hydraulic conductivity of this layer was set at the relatively low value of $0.033 \mathrm{ft} / \mathrm{d}$.

Average flow conditions are simulated in the calibrated model prior to simulating remediation extraction (fig. 9). The contour map of water level in the intermediate model layer 7 indicates general flow directions are from west to east, toward Rock Creek. Model layer 7 represents bedrock between 131 and $156 \mathrm{ft}$ bls; extraction well AD-713 is located in model layer 7.

The root mean square residual for all water-level comparisons (simulated and measured) is $3.6 \mathrm{ft}$, with ground-water-level differences from -9.4 to $+8.6 \mathrm{ft}$ for the simulation without extraction wells pumping (bottom left boundary, fig. 9). Differences between measured and simulated drawdown after 24 hours of pumping the seven extraction wells indicate local heterogeneity is not fully accounted for in the model (table 6). Some of the differences also may be the result of the methods used to estimate the drawdown from available measurements. The available measurements do not directly correspond to the conditions simulated in which all extraction wells are started at the same time and pumped at constant rates. 
Table 6. Water-level measurements used for calibration of the ground-water-flow model at the Gettysburg Elevator Plant Superfund Site, Gettysburg, Pennsylvania

[ft swl, feet above sea level; --, not measured, extraction well; negative values indicate that simulated waterlevel altitudes are less than observed water-level altitudes]

\begin{tabular}{|c|c|c|c|c|c|}
\hline \multirow{3}{*}{$\begin{array}{c}\text { Well } \\
\text { number }\end{array}$} & \multirow{3}{*}{$\begin{array}{l}\text { Model } \\
\text { layer }\end{array}$} & \multicolumn{4}{|c|}{ Comparison between observed and simulated water levels } \\
\hline & & \multicolumn{2}{|c|}{$\begin{array}{l}\text { For simulation without extraction wells } \\
\text { pumping }\end{array}$} & \multicolumn{2}{|c|}{$\begin{array}{c}\text { For simulation after } \\
24 \mathrm{hrs} \text { of extraction wells pumping }\end{array}$} \\
\hline & & $\begin{array}{l}\text { Observed } \\
\text { (ft swl) }\end{array}$ & $\begin{array}{c}\text { Difference between } \\
\text { simulated and observed } \\
\text { (feet) }\end{array}$ & $\begin{array}{c}\text { Observed } \\
\text { drawdown residual } \\
\text { (feet) }\end{array}$ & $\begin{array}{l}\text { Simulated drawdown } \\
\text { residual } \\
\text { (feet) }\end{array}$ \\
\hline AD-654 & 3 & 532.76 & 2.00 & 0.00 & 1.54 \\
\hline AD-655 & 9 & 532.63 & -3.32 & .00 & 3.53 \\
\hline AD-656 & 5 & 531.04 & -1.13 & -- & -- \\
\hline AD-657 & 3 & 541.90 & -9.38 & .49 & .11 \\
\hline AD-658 & 9 & 530.21 & -2.44 & .98 & .25 \\
\hline AD-659 & 3 & 548.12 & -2.06 & .00 & .27 \\
\hline AD-660 & 7 & 543.88 & -1.04 & .00 & .85 \\
\hline AD-661 & 10 & 540.67 & -.29 & 2.95 & .76 \\
\hline AD-662 & 9 & 533.07 & 5.43 & .00 & .28 \\
\hline AD-663 & 7 & 557.14 & 8.65 & .00 & .22 \\
\hline AD-664 & 3 & 539.99 & 1.08 & .00 & .27 \\
\hline AD-665 & 9 & 543.93 & -2.03 & .00 & 1.25 \\
\hline AD-666 & 3 & 525.39 & 1.18 & 4.00 & .51 \\
\hline AD-667 & 6 & 524.12 & 5.19 & 19.68 & 3.51 \\
\hline AD-668 & 3 & 532.32 & -1.97 & 9.84 & 1.59 \\
\hline AD-669 & 8 & 529.54 & -2.53 & .98 & 1.32 \\
\hline AD-670 & 3 & 517.91 & -1.32 & .00 & .08 \\
\hline AD-671 & 10 & 514.58 & -.69 & 2.95 & .32 \\
\hline AD-672 & 3 & 533.57 & -5.27 & .00 & .02 \\
\hline AD-673 & 5 & 530.19 & -.01 & .00 & .07 \\
\hline AD-674 & 3 & 520.29 & -1.68 & .00 & .12 \\
\hline AD-675 & 8 & 517.23 & -1.36 & .00 & .45 \\
\hline AD-676 & 3 & 526.02 & 4.74 & .98 & 2.70 \\
\hline AD-677 & 8 & 524.06 & 5.34 & 9.84 & 11.63 \\
\hline AD-678 & 8 & 512.49 & -5.29 & .00 & .31 \\
\hline AD-679 & 3 & 517.25 & -4.31 & .00 & .22 \\
\hline AD-680 & 8 & 505.78 & 5.31 & 2.95 & .73 \\
\hline AD-681 & 9 & 523.81 & 6.75 & 4.00 & .49 \\
\hline AD-682 & 5 & 497.21 & .71 & .00 & .67 \\
\hline AD-683 & 4 & 531.02 & -1.41 & -- & -- \\
\hline AD-684 & 12 & 495.42 & .19 & .00 & .43 \\
\hline AD-685 & 6 & 502.30 & 1.13 & 2.95 & .47 \\
\hline AD-686 & 9 & 511.00 & 1.77 & .00 & .66 \\
\hline AD-687 & 3 & 508.01 & 1.74 & .00 & .22 \\
\hline AD-688 & 9 & 523.91 & 5.58 & -- & -- \\
\hline AD-689 & 11 & 501.93 & 1.73 & 4.92 & .59 \\
\hline AD-690 & 11 & 511.03 & 1.56 & 2.95 & .70 \\
\hline AD-691 & 8 & 503.16 & -2.32 & .00 & 1.42 \\
\hline AD-692 & 3 & 519.74 & -3.58 & -- & -- \\
\hline
\end{tabular}


Table 6. Water-level measurements used for calibration of the ground-water-flow model at the Gettysburg Elevator Plant Superfund Site, Gettysburg, Pennsylvania-Continued

[ft swl, feet above sea level; --, not measured, extraction well; negative values indicate that simulated waterlevel altitudes are less than observed water-level altitudes]

\begin{tabular}{|c|c|c|c|c|c|}
\hline \multirow{3}{*}{$\begin{array}{l}\text { Well } \\
\text { number }\end{array}$} & \multirow{3}{*}{$\begin{array}{l}\text { Model } \\
\text { layer }\end{array}$} & \multicolumn{4}{|c|}{ Comparison between observed and simulated water levels } \\
\hline & & \multicolumn{2}{|c|}{$\begin{array}{l}\text { For simulation without extraction wells } \\
\text { pumping }\end{array}$} & \multicolumn{2}{|c|}{$\begin{array}{c}\text { For simulation after } \\
24 \mathrm{hrs} \text { of extraction wells pumping }\end{array}$} \\
\hline & & $\begin{array}{c}\text { Observed } \\
\text { (ft swl) }\end{array}$ & $\begin{array}{c}\text { Difference between } \\
\text { simulated and observed } \\
\text { (feet) }\end{array}$ & $\begin{array}{c}\text { Observed } \\
\text { drawdown residual } \\
\text { (feet) }\end{array}$ & $\begin{array}{l}\text { Simulated drawdown } \\
\text { residual } \\
\text { (feet) }\end{array}$ \\
\hline AD-695 & 5 & 501.95 & -2.31 & 7.00 & 0.64 \\
\hline AD-696 & 9 & 498.62 & .56 & 5.00 & .92 \\
\hline AD-697 & 11 & 496.42 & 2.84 & 2.99 & .99 \\
\hline AD-710 & 9 & 503.77 & 1.72 & 4.00 & 1.00 \\
\hline AD-711 & 9 & 503.32 & -2.15 & .00 & .25 \\
\hline AD-712 & 9 & 506.20 & 5.59 & -- & -- \\
\hline AD-713 & 7 & 502.31 & 1.44 & -- & -- \\
\hline AD-714 & 8 & 497.88 & 1.78 & -- & -- \\
\hline AD-715 & 13 & 532.41 & 4.91 & 9.84 & 1.68 \\
\hline AD-716 & 15 & 532.00 & 5.57 & 2.95 & 1.63 \\
\hline
\end{tabular}




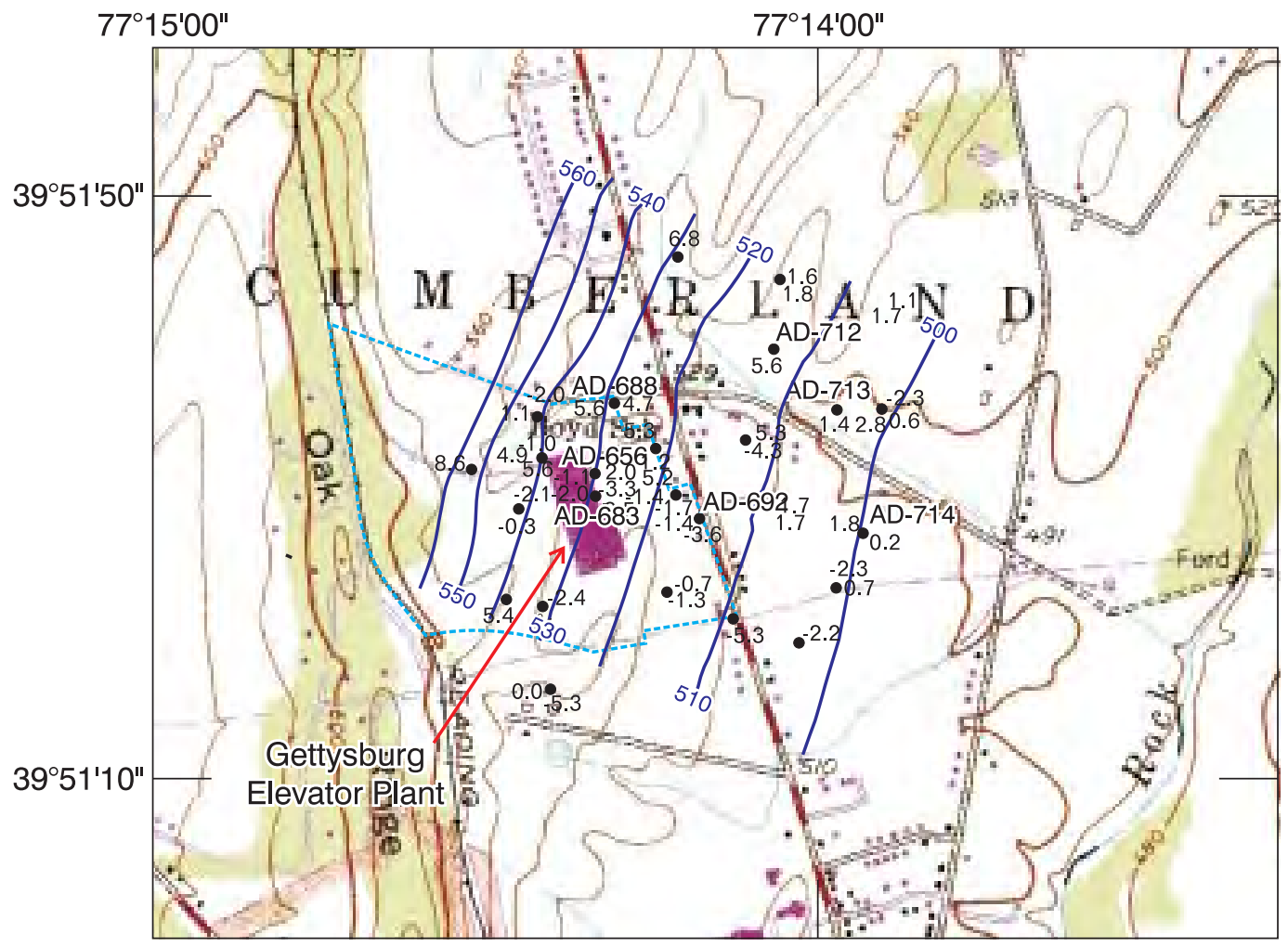

Base from U.S. Geological Survey Gettysburg 1:24,000 1981

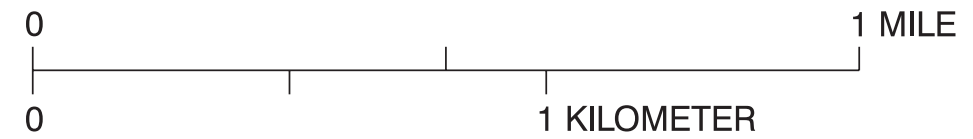

\section{EXPLANATION \\ APPROXIMATE LOCATION OF GETTYSBURG} ELEVATOR PLANT SUPERFUND SITE

- SIMULATED WATER-LEVEL ALTITUDE CONTOUR, IN FEET (10 FOOT CONTOUR INTERVAL) AD-714 ACTIVE PUMPING WELL

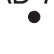

-2.2 MODEL HEAD RESIDUAL AT WELL LOCATION,

IN FEET (Residuals have been rounded to one decimal place)

Figure 9. Simulated potentiometric surface under no-pumping steady-state conditions in model layer 7 representing unweathered, fractured bedrock between 131 and 156 feet below land surface at the Gettysburg Elevator Plant Superfund Site, Gettysburg, Pennsylvania. The model head residual is the simulated water level minus the observed water level. 


\section{Estimated Large-Scale Hydraulic Conductivity and Recharge}

The calibrated model parameters are estimates of the local hydraulic properties affecting groundwater flow at the Elevator Site. Calibrated parameters and normalized sensitivities are shown in table 7. The normalized sensitivities indicate which model parameters are more tightly constrained by the measured water levels and drawdown. In general, the simulated water levels are subject to greater proportional changes in areas where the model parameters have larger normalized sensitivities. These sensitivities are evaluated only at the calibrated model values and would change with a different model configuration. The model calibration error, which depends on the simulated water levels, is most sensitive to the hydraulic conductivity of zone 2, and least sensitive to the hydraulic conductivity of zones 8 and 9 . The major result from the estimation of hydraulic properties is that the beds open to extraction wells (zones 6-9) are estimated to have larger hydraulic conductivity than the beds that lie between the pumped beds (zones 2-4). These results are consistent with previously postulated conceptual models of groundwater flow at the Elevator Site (Cummings/Riter, 1998).

Table 7. Optimum values for storage coefficient and hydraulic conductivity and normalized sensitivity of hydraulic conductivity parameters for calibrated simulation of ground-water flow at the Gettysburg Elevator Plant Superfund Site, Gettysburg, Pennsylvania

\begin{tabular}{cccc}
\hline Zone & $\begin{array}{c}\text { Storage } \\
\text { coefficient } \\
\text { (dimensionless) }\end{array}$ & $\begin{array}{c}\text { Hydraulic } \\
\text { conductivity } \\
\text { (feet per day) }\end{array}$ & $\begin{array}{c}\text { Normalized sensitivity of } \\
\text { hydraulic conductivity parameter } \\
\text { (feet) }\end{array}$ \\
\hline 1 - Offsite west & $13 \times 10^{-7}$ & 0.026 & 2.8 \\
2 - Unpumped & $3 \times 10^{-7}$ & .069 & 5.3 \\
3 - Unpumped & $3 \times 10^{-7}$ & .052 & 1.8 \\
4 - Unpumped & $3 \times 10^{-7}$ & .30 & .98 \\
5 - Offsite east & $3 \times 10^{-7}$ & 2.26 & .52 \\
6 - Pumped & $3 \times 10^{-9}$ & 1.52 & .76 \\
7 - Pumped & $23 \times 10^{-9}$ & 5.51 & .18 \\
8 - Pumped & $3 \times 10^{-9}$ & 32.30 & .068 \\
9 - Pumped & $3 \times 10^{-9}$ & 2.30 & .068 \\
\hline
\end{tabular}

\footnotetext{
${ }^{1}$ Specific storage of zones $1,2,3,4$, and 5 is a single parameter.

${ }^{2}$ Specific storage of zones $6,7,8$, and 9 is a single parameter.

${ }^{3}$ Hydraulic conductivity of zones 8 and 9 is a single parameter.
}

\section{Limitations and Uncertainties}

The contributing areas for extraction wells in the site area are approximated by simulations presented in this report. Although the calibrated models match many of the measured water levels and water-level changes during pumping, the water-level measurements are not precisely reproduced in the models. The actual ground-water flowpaths are likely to be more complex than those shown here because of the highly heterogeneous characteristics of the bedrock zone and changing recharge and pumping conditions. The results here can be used to compare alternative ground-water-management methods and to indicate general characteristics of contributing areas for these wells. The uncertainties in the simulations could be reduced by more detailed field studies and longer-term aquifer and tracer tests, which are beyond the scope of this study. 


\section{Effect of Pumping on Ground-Water Flow}

Particle tracking using MODPATH (Pollock, 1994) illustrates the paths of ground-water flow simulated in the flow model. On the basis of the calibrated hydraulic conductivity and the computed three-dimensional hydraulic gradients, water particles are tracked through the flow system from recharge to discharge locations in streams or wells. Recharge along a ground-water divide may flow deep through the system, beneath the three-dimensional capture zone of a nearby stream, and discharge to a moredistant regional boundary. The land-surface areas that contribute recharge to the extraction wells (contributing areas) were delineated by backtracking particles from each model cell containing a well to land surface.

Ground-water withdrawals from extraction wells on and outside of the Elevator Site have a major effect on the local water budget and flowpaths. The water budget simulated for the 1996 pumping rates (table 8 ) indicates about 9 percent of the ground-water recharge on the model area discharges to extraction wells. The ground-water withdrawals cause a reduction in streamflow by capturing ground water that would have discharged to streams in the absence of extraction pumping. Comparison of stream leakage into the model for simulations with and without the extraction-well pumping indicates that the wells only induce a small amount (less than $1 \mathrm{gal} / \mathrm{min}$ ) of stream-water infiltration.

Table 8. Steady-state water budgets for the ground-water system simulated in the model, Gettysburg Elevator Plant Superfund Site, Gettysburg, Pennsylvania

[gal/min, gallons per minute]

\begin{tabular}{c|c|c}
\hline Water budget component & $\begin{array}{c}\text { Simulation without } \\
\text { pumping from } \\
\text { extraction wells } \\
\text { (gal/min) }\end{array}$ & $\begin{array}{c}\text { Simulation with } \\
\text { pumping from } \\
\text { extraction wells } \\
\text { (gal/min) }\end{array}$ \\
\hline Inflow & \\
Areal recharge & 528 & 528 \\
Stream leakage & 1.0 & 2.0 \\
Total & 529 & 530 \\
Stream leakage & Outflow & 482 \\
Wells & 529 & 47 \\
Total & 0.0 & 1530 \\
\hline
\end{tabular}

\footnotetext{
${ }^{1}$ Numbers do not add up to the total shown because of rounding.
} 
Contributing areas to the extraction wells are shown in figure 10. The contributing area for each well is directly proportional to the extraction rate because recharge was simulated at a uniform rate in the model. The heterogeneous hydraulic properties of the bedrock, differing depths of the extraction wells, and hydrologic connection between streams and the ground-water system all affect the complex pattern of the simulated contributing areas. The simulated contributing areas shown in figure 10 indicate that about

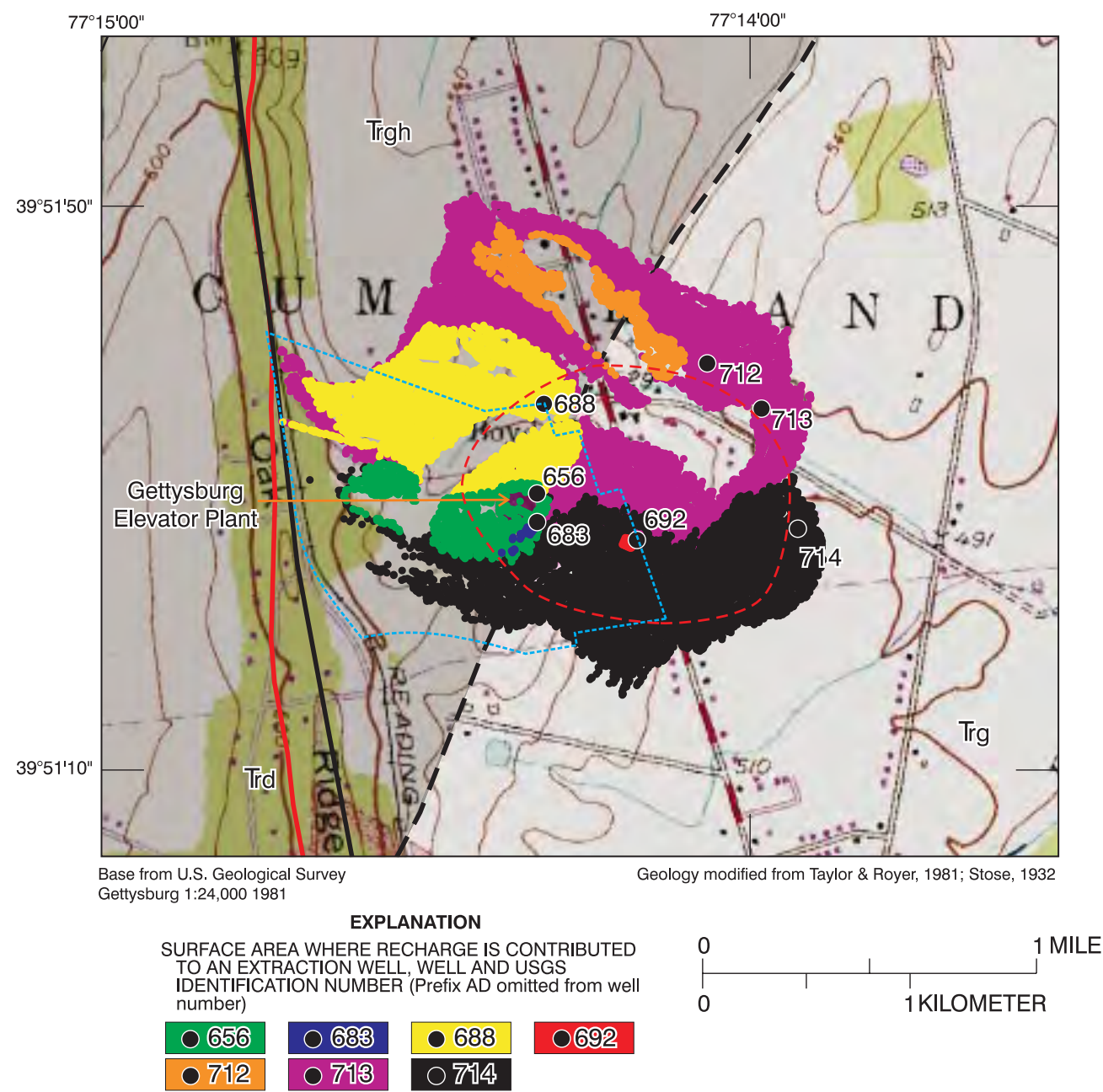

\begin{tabular}{|c|c|}
\hline $\begin{array}{c}\text { Trgh GETTYSBURG FORMATION } \\
\text { Heidlersburg Member }\end{array}$ & 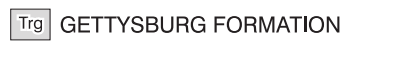 \\
\hline - MODEL BOUNDARY & - - INFERRED GEOLOGIC CONTACT \\
\hline $\begin{array}{l}\text { Ird DIABASE DIKE } \\
-10 \text { MICROGRAM PER LITER } \\
\text { TOTAL VOLATILE ORGANIC } \\
\text { CONCENTRATION } \\
\text { ISOCONCENTRATION LINE }\end{array}$ & $\begin{array}{l}\text { APPROXIMATE LOCATION OF } \\
\text { GETTYSBURG ELEVATOR } \\
\text { PLANT SUPERFUND SITE }\end{array}$ \\
\hline
\end{tabular}

Figure 10. Simulated contributing areas to extraction wells under long-term steady-state conditions at the Gettysburg Elevator Plant Superfund Site, Gettysburg, Pennsylvania. 
67 percent of ground-water recharge on the plant property is captured by the onsite and offsite extraction wells (table 9). Simulations indicate that about 8 percent of the recharge infiltrating near streams on the Elevator Site discharges directly to streams despite withdrawals from the extraction wells. This simulated ground-water contribution to onsite streams, in terms of discharge rate, is about $2.5 \mathrm{gal} / \mathrm{min}$, an amount that probably would be lost to evapotranspiration in the stream channel during most of the year. About 26 percent of recharge on the Elevator Site, mostly in the southern and western parts of the site, discharges offsite to tributaries of Rock Creek.

Table 9. Estimates of ground-water recharge from the Gettysburg Elevator Plant Superfund Site that is captured by extraction wells, Gettysburg, Pennsylvania

[gal/min, gallons per minute; --, not determined]

\begin{tabular}{ccccc}
\hline Well number & $\begin{array}{c}\text { Pumping rate used } \\
\text { in model simulation } \\
\text { (gal/min) }\end{array}$ & $\begin{array}{c}\text { Total contributing } \\
\text { area to } \\
\text { extraction well } \\
\text { (square feet) }\end{array}$ & $\begin{array}{c}\text { Percentage of } \\
\text { contributing area to } \\
\text { extraction well } \\
\text { from Elevator Site }\end{array}$ & $\begin{array}{c}\text { Percentage of } \\
\text { recharge on } \\
\text { Elevator Site } \\
\text { captured by } \\
\text { extraction well }\end{array}$ \\
\hline AD-656 & 3.0 & 361,600 & 100 & 12.0 \\
AD-683 & .06 & 7,232 & 100 & .6 \\
AD-688 & 9.0 & $1,085,000$ & 58.3 & 21.1 \\
AD-692 & .01 & 1,205 & 100 & .4 \\
AD-712 & 2.0 & 241,100 & 0 & 0 \\
AD-713 & 18 & $2,169,000$ & 8.3 & 4.7 \\
AD-714 & 15 & $1,808,000$ & 47.2 & 27.9 \\
Total & 47.07 & $15,673,000$ & -- & 66.7 \\
\hline
\end{tabular}

${ }^{1}$ Numbers do not add up to the total shown because of rounding.

The contributing areas for onsite and offsite extraction wells are shown separately in figures 11 and 12. Three of the four onsite extraction wells (AD-656, AD-683, and AD-692) only capture ground-water recharge from the Elevator Site (fig. 11). The contributing areas for extraction wells AD-683 and AD-692 are relatively small and located immediately surrounding the wells because they are shallow wells with small withdrawal rates. The deepest onsite extraction well with the largest pumping rate (AD-688) captures about 57 percent from onsite recharge (table 9); its capture zone is a complex shape that wraps around an area that contributes water directly to an onsite stream (fig. 11). The contributing area for extraction well AD-656 is bisected by a stream. This divides the contributing area for extraction well AD-656 into two separate parts.

Contributing areas for the three offsite extraction wells (AD-712, AD-713, and AD-714) are shown in figure 12. Wells AD-713 and AD-714 have the largest contributing areas because they are extracting water at the greatest rates (table 9). Both these offsite extraction wells capture some ground water that was recharged on the Elevator Site. About 46 percent of the water captured by AD-714 was contributed from onsite recharge, mostly from the southern part of the Elevator Site. Model simulations indicate AD-714 captures more ground-water recharge from the Elevator Site than any of the other extraction wells.

The simulation results generally indicate the extraction system effectively captures much of the ground-water recharge at the site. Some wells pumping at low rates have very small contributing areas. The simulation indicates some recharge that occurs onsite will migrate to offsite pumping wells. These results can be most effectively verified by continued monitoring of the water levels and water quality in the monitor-well network. 


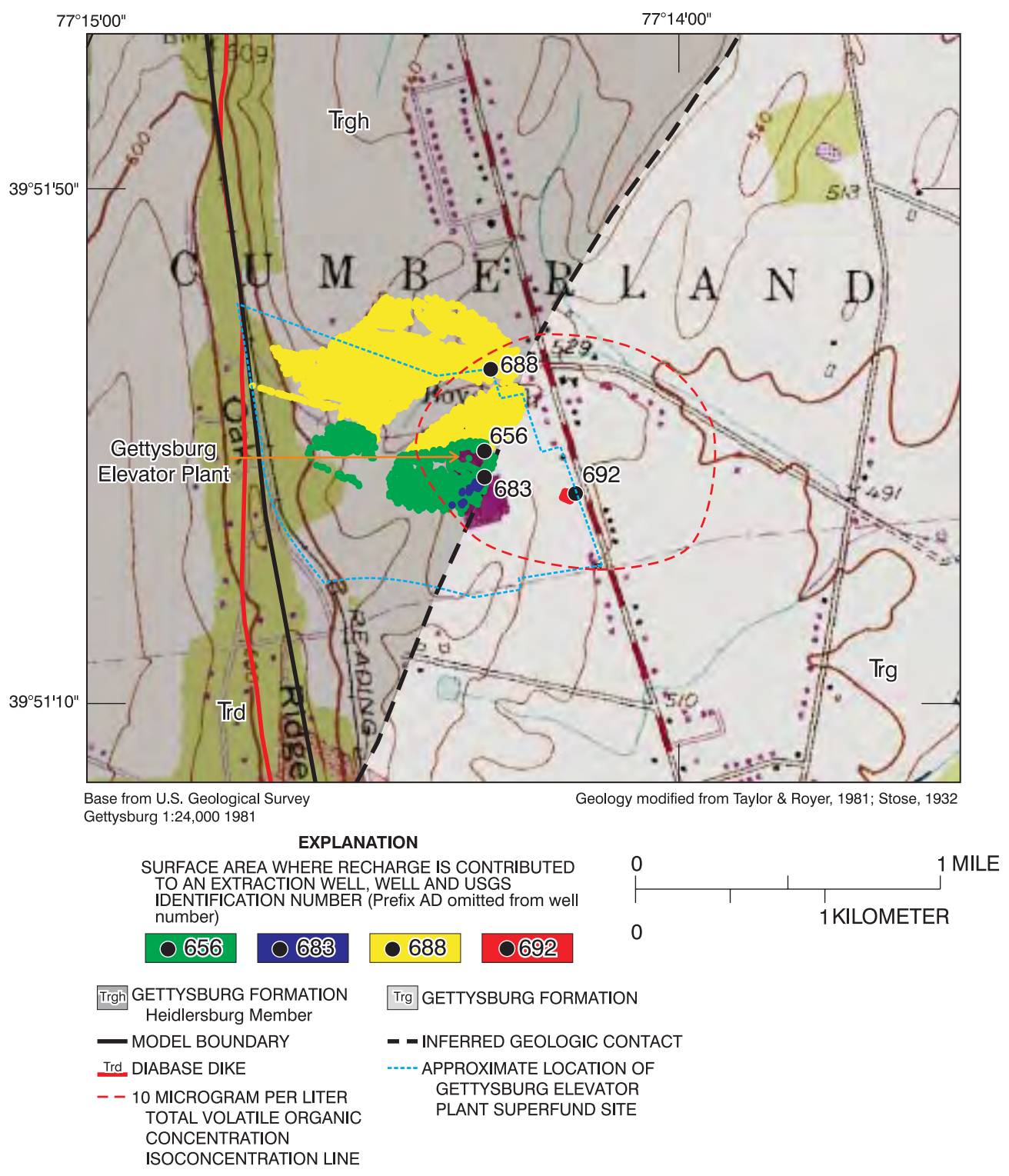

Figure 11. Simulated contributing areas to onsite extraction wells under long-term steadystate conditions at the Gettysburg Elevator Plant Superfund Site, Gettysburg, Pennsylvania. 


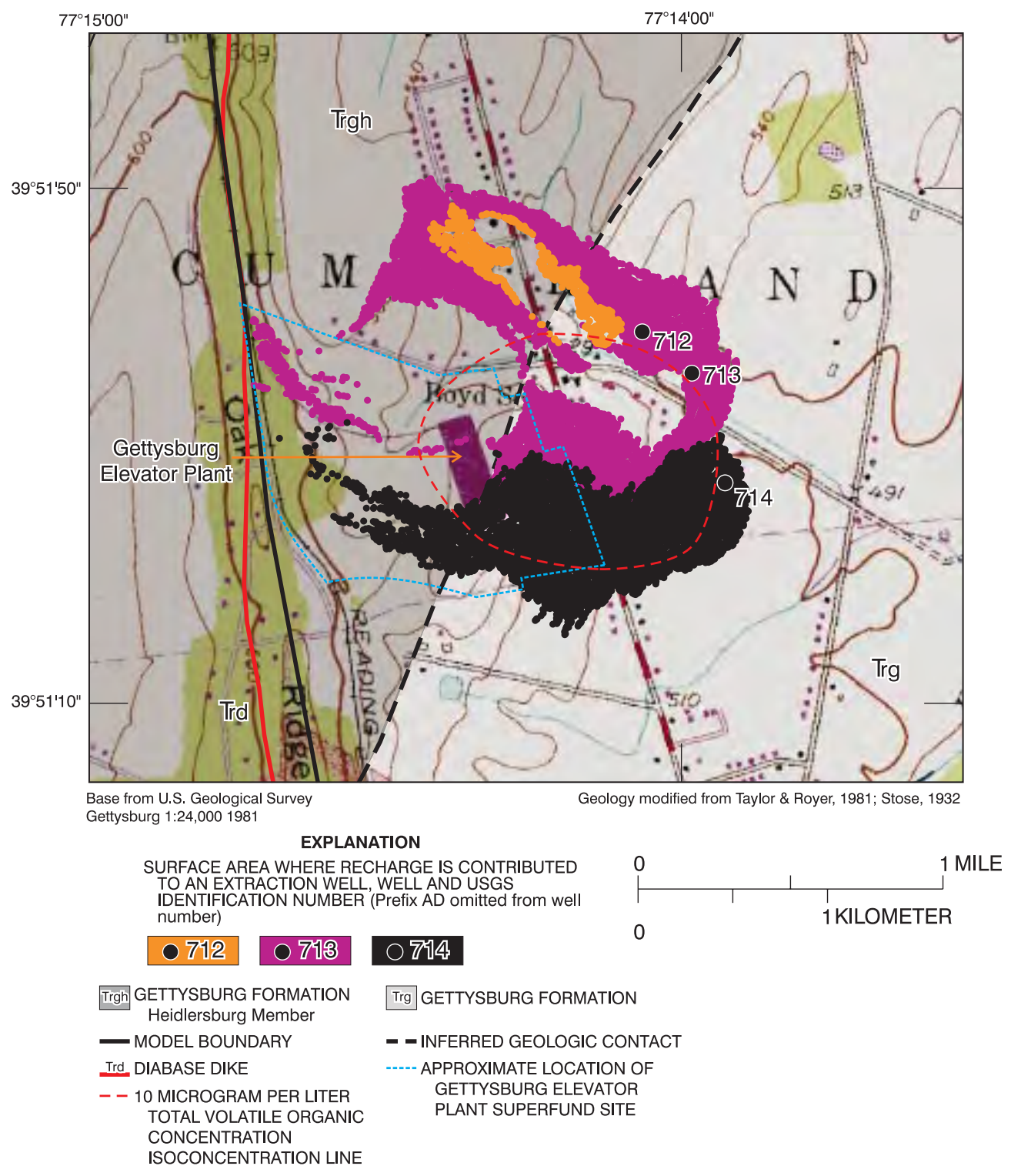

Figure 12. Simulated contributing areas to offsite extraction wells under long-term steadystate conditions at the Gettysburg Elevator Plant Superfund Site, Gettysburg, Pennsylvania. 


\section{SUMMARY}

This report describes the results of a 3-year study by the U.S. Geological Survey, in cooperation with the U.S. Environmental Protection Agency, to determine the effects of onsite and offsite extraction wells on ground-water flow and contaminant migration from the Gettysburg Elevator Plant Superfund Site, Adams County, Pa. In 1983, ground water at the Gettysburg Elevator Plant was found by the Pennsylvania Department of Environmental Resources to be contaminated with trichloroethene, 1,1,1-trichloroethane, and other synthetic organic compounds. This study is based on hydrologic and geophysical data collected from 1991 to 1998 and on results of numerical model simulations of the ground-water flow system in the vicinity of the site.

Geology at the Elevator Site consists of Triassic-age sedimentary rocks of the Gettysburg Formation. Bedrock strikes about N. $23^{\circ}$ E. and dips about $23^{\circ}$ NW. Geology at the Elevator Site consists of Triassic-age sedimentary rocks of the Gettysburg Formation. These red, green, gray, and black shales strike about N. $23^{\circ}$ E. and dip about $23^{\circ} \mathrm{NW}$. Triassic to Jurassic-age intrusive dikes of diabase mark the western border of the Elevator Site.

The ground-water system underlying the Elevator Site consists of a thin (6-ft thick) shallow zone composed of soil, clay, and highly weathered bedrock and a thicker, nonweathered or fractured bedrock zone. The shallow zone overlies the bedrock zone and truncates the dipping beds parallel to land surface. Diabase dikes are barriers to ground-water flow in the bedrock zone. The ground-water system is considered confined, even at shallow depths. Ground water in the bedrock zone flows through discrete secondary openings towards Rock Creek. These secondary openings have considerably greater hydraulic conductivities than the surrounding bedrock. Water levels in monitor wells completed in the same dipping bed as an extraction well will have greater drawdowns than monitor wells that are not open to the pumped bed.

Ground-water flow was simulated by use of MODFLOW for steady-state conditions prior to pumping of extraction wells and long-term average pumping of the onsite and offsite extraction wells. MODFLOW was automatically calibrated by use of a parameter estimation program (MODFLOWP). Steady-state conditions were assumed for the calibration period of 1996. An areal recharge rate of $7 \mathrm{in}$. was used in model simulation. The model was developed with 16 layers to represent the $511-\mathrm{ft}$ thickness of the shallow and bedrock zones. The area of the model domain is about $2.3 \mathrm{mi}^{2}$. The shallow zone is represented by model layer 1 and is uniformly 6 -ft thick across the model area. The bedrock zone is represented by model layers 2 through 16. Four high hydraulic-conductivity beds (zones 6-9) were included and represent the beds that are pumped by extraction wells AD-656, AD-683, AD-688, AD-712, AD-713, and AD-714. To approximate the effect of the dipping beds on ground-water flow, the four high hydraulic-conductivity beds were simulated in layers 2-16 in a stair-step configuration. This configuration accounted for much of the apparent anisotropy observed at the Elevator Site.

The simulation results indicate the extraction system captures about 67 percent of the ground-water recharge at the Elevator Site and most of the contaminated ground water migrating from the site. Extraction wells AD-656, AD-683, and AD-692 capture all of their water onsite. Extraction wells AD-688, AD-713, and AD-714 capture about 58, 8, and 47 percent of their water onsite, respectively. Extraction well AD-712 captures all of its water from offsite sources. 


\section{REFERENCES}

Berg, T.M., Barnes, J.H., Sevon, W.D., Skema, V.W., Wilshusen, J.P., and Yannacci, D.W., 1989, Physiographic provinces of Pennsylvania: Pennsylvania Geological Survey, 4th ser., map 13 (color), scale $1: 2,000,000,8.5 \times 11$ inches.

Cummings/Riter, Inc., 1995, Remedial design investigation report, Gettysburg Elevator Plant Site, Adams County, Pennsylvania: Monroeville, Pa., Cummings/Riter Consultants, Inc., variously paged.

1996, Supplemental preliminary remedial design submittal (revision 1.0), Gettysburg Elevator Plant Site, Adams County, Pennsylvania: Monroeville, Pa., Cummings/Riter Consultants, Inc., variously paged.

1997, Final design report, Gettysburg Elevator Plant Site, Adams County, Pennsylvania: Monroeville, Pa., Cummings/Riter Consultants, Inc., variously paged.

1998, Approved final remedial design report and approved interim remedial action report, Gettysburg Elevator Plant Site, Adams County, Pennsylvania: Monroeville, Pa., Cummings/Riter Consultants, Inc., variously paged.

Fenneman, N.M., 1938, Physiography of eastern United States: New York, McGraw-Hill Book Company, Inc., $691 \mathrm{p}$.

Gerhart, J.M., and Lazorchick, G.J., 1988, Evaluation of the ground-water resources of the Lower Susquehanna River Basin, Pennsylvania and Maryland: U.S. Geological Survey Water-Supply Paper 2284, $128 \mathrm{p}$.

Harbaugh, A.W., and McDonald, M.G., 1996, User's documentation for MODFLOW-96, an update to the U.S. Geological Survey modular finite-difference ground-water flow model: U.S. Geological Survey Open-File Report 96-485, 56 p.

Heath, R.C., 1983, Basic ground-water hydrology: U.S. Geological Survey Water-Supply Paper 2220, 84 p.

Hill, M.C., 1992, A computer program (MODFLOWP) for estimating parameters of a transient, threedimensional ground-water flow model using nonlinear regression: U.S. Geological Survey OpenFile Report 91-484, 358 p.

Lewis-Brown, J.C., and Jacobsen, Eric, 1995, Hydrogeology and ground-water flow, fractured Mesozoic structural-basin rocks, Stony Brook, Beden Brook, and Jacobs Creek drainage basins, West-Central New Jersey: U.S. Geological Survey Water-Resources Investigations Report 94-4147, 83 p.

Low, D.J., and Dugas, D.L., 1999, Summary of hydrogeologic and ground-water-quality data and hydrogeologic framework at selected well sites, Adams County, Pennsylvania: U.S. Geological Survey Water-Resources Investigations Report 99-4108, 86 p.

McDonald, M.G., and Harbaugh, A.W., 1988, A modular three-dimensional finite-difference ground-water flow model: U.S. Geological Survey Techniques of Water-Resources Investigations, book 6, chap. A1, $586 \mathrm{p}$.

National Oceanic and Atmospheric Administration, 1993, Climatological data annual summary, Pennsylvania: U.S. Department of Commerce, v. 98, no 13.

1994, Climatological data, Pennsylvania: U.S. Department of Commerce, v. 99, no. 3 - 12.

1995, Climatological data, Pennsylvania: U.S. Department of Commerce, v. 100, no. 1.

Pollock, D.W., 1994, User's guide for MODPATH/MODPATH-PLOT, version 3: a particle tracking postprocessing package for MODFLOW, the U.S. Geological Survey finite-difference ground-water flow model: U.S. Geological Survey Open-File Report 94-464, 249 p.

Rizzo Associates, Inc., 1991, Remedial investigation report, Westinghouse Plant Site, Cumberland Township, Adams County, Pennsylvania: Monroeville, Pa., Paul C. Rizzo Associates, Inc., variously paged. 


\section{REFERENCES-Continued}

Root, S.I., 1989, Basement control of structure in the Gettysburg rift basin, Pennsylvania and Maryland: Tectonophysics, v. 166, p. 281-292.

Schreffler, C.L., 1996, Hydrogeologic framework of the diabase aquifer at the Boarhead Farms Superfund Site, Bridgeton Township, Bucks County, Pennsylvania: U.S. Geological Survey Water-Resources Investigations Report 96-4090, 58 p.

Shapiro, A.M., Margolin, Joshua, Dolev, Shahar, and Ben-Israel, Yaacov, 1997, A graphical-user interface for the U.S. Geological Survey modular three-dimensional finite-difference ground-water flow model (MODFLOW-96) using argus numerical environments: U.S. Geological Survey Open-File Report 97-121, 50 p.

Stose, G.W., 1932, Geology and mineral resources of Adams County, Pennsylvania: Pennsylvania Geological Survey, 4th ser., Bulletin C 1, 153 p.

Taylor, L.E., and Royer, D.W., 1981, Summary groundwater resources of Adams County, Pennsylvania: Pennsylvania Geological Survey, 4th ser., Water Resource Report 52, 50 p.

U.S. Environmental Protection Agency, 1992, Record of decision, Westinghouse Elevator Company Plant, Operable Unit 1, U.S. Environmental Protection Agency Docket No. III-93-12-DC, 66 p.

Winston, R.B., 1999, Upgrade to MODFLOW-GUI: Addition of MODPATH, ZONEBDGT, and additional MODFLOW packages: U.S. Geological Survey Open-File Report 99-184, 63 p.

Wood, C.R., 1980, Groundwater resources of the Gettysburg and Hammer Creek Formations, southeastern Pennsylvania: Pennsylvania Geological Survey, 4th ser., Water Resource Report 49, 87 p. 